Old Dominion University

ODU Digital Commons

Spring 2016

\title{
Effects of Learner-to-Learner Interactions on Social Presence, Achievement and Satisfaction
}

Susan Elizabeth Allred Oyarzun

Old Dominion University, beth@oyarzun.net

Follow this and additional works at: https://digitalcommons.odu.edu/stemps_etds

Part of the Curriculum and Instruction Commons, Educational Assessment, Evaluation, and Research Commons, and the Online and Distance Education Commons

\section{Recommended Citation}

Allred Oyarzun, Susan E.. "Effects of Learner-to-Learner Interactions on Social Presence, Achievement and Satisfaction" (2016). Doctor of Philosophy (PhD), Dissertation, STEM Education \& Professional Studies, Old Dominion University, DOI: 10.25777/6ya8-zk73

https://digitalcommons.odu.edu/stemps_etds/6

This Dissertation is brought to you for free and open access by the STEM Education \& Professional Studies at ODU Digital Commons. It has been accepted for inclusion in STEMPS Theses \& Dissertations by an authorized administrator of ODU Digital Commons. For more information, please contact digitalcommons@odu.edu. 


\title{
EFFECTS OF LEARNER-TO-LEARNER INTERACTIONS
}

ON SOCIAL PRESENCE, ACHIEVEMENT AND SATISFACTION

\author{
by
}

Susan Elizabeth Allred Oyarzun

M.S. Instructional Technology, May 2005, University of North Carolina Wilmington B.A. Mathematics, May 1996, University of North Carolina Wilmington

A Dissertation Submitted to the Faculty of Old Dominion University in Partial Fulfillment of the Requirements for the Degree of DOCTOR OF PHILOSOPHY INSTRUCTIONAL TECHNOLOGY OLD DOMINION UNIVERSITY

May 2016

Approved by:

Linda Bol (Co-Director)

Jill Stefaniak (Co-Director)

Gary R. Morrison (Member) 


\author{
ABSTRACT \\ EFFECTS OF LEARNER-TO-LEARNER INTERACTIONS \\ ON SOCIAL PRESENCE, ACHIEVEMENT AND SATISFACTION \\ Susan Elizabeth Allred Oyarzun \\ Old Dominion University, 2016 \\ Co-Director: Dr. Linda Bol \\ Co-Director: Dr. Jill Stefaniak
}

The relationships between learner-to-learner interactions, achievement, social presence, and satisfaction in online learning have varying degrees of strength according to the research. More evidence is needed to identify clarify relationships among these variables and to identify best practices for designing learner-to-learner interactions to increase achievement, level of social presence, and learner satisfaction. This nonexperimental, comparative study investigated the strategies used for learner-to-learner interactions effects on achievement, social presence, and satisfaction. Surveys measuring social presence and interaction quality were administered to instructors and students enrolled in 17 undergraduate asynchronous online courses. The surveys for instructors and students were the same, except for slight modifications to address the appropriate audience. A survey measuring learning satisfaction was only administered to the students. Achievement measures were collected via three performance ratings from the instructors. Designed interactions that have a cooperative intent increased learner's achievement and level of satisfaction.

Designed interactions should include (a) positive interdependence; (b) individual accountability; (c) promotive interactions, and (d) elaborate explanations. 
The effect social presence had on achievement, satisfaction, and interaction quality were mixed. A higher level of instructor social presence increases learner's achievement, level of learner social presence, and level of learner satisfaction. A higher level of learner social presence increases level of interactive quality and level of learner satisfaction. The findings suggest that higher levels of interaction quality increased levels of instructor social presence, learner social presence, and learner satisfaction. The quality of interaction may be a stronger predictor for level of social presence and learner satisfaction. More research in this area is needed to validate this conclusion. Further research is also recommended to identify and validate the relationships between these variables and best practices in designing interactive experiences in online asynchronous undergraduate courses. 
Copyright, 2016, by Susan Elizabeth Allred Oyarzun, All Rights Reserved. 
This dissertation is dedicated to my daughter, Patricia.

With persistence, patience, and hard work you can achieve whatever you desire. 


\section{ACKNOWLEDGEMENTS}

There are many individuals that have been supportive in the completion of this dissertation. The members of my committee at Old Dominion have been guiding lights and I extend my thanks to them for their many hours of work. Dr. Gary Morrison guided me as my advisor until his retirement and continued on my committee post retirement. I am honored to be your last student. I am also thankful that you agreed to see me through to the end. Dr. Linda Bol and Dr. Jill Sefaniak have guided as co-directors of my committee. Thank you both for your constructive and quick feedback.

My colleagues and friends at UNCW have also contributed to the successful completion of this work. I extend my appreciation to them for their support and assistance. Mrs. Sheri Conklin has been my partner in crime for too many years to count. Thank you for being the other half of my brain. Dr. Florence Martin has mentored me through my first few research studies. Thank you for your patience and dedication. A special thank you to all of my colleagues that participated in this study or listened to me talk about it over the past year and a half.

My family has provided support in too many ways to mention. I want to thank my parents, Don and Pat Allred, for their belief and support through all of my degrees. They never realized that I would be in college until I was forty-three. I promise that I am done. To my extended family, particularly Susan and Ron Singletary, thank you for your support and guidance as well. You all are the best cheerleaders. Thank you to my wonderful husband, Christian, for your support and putting up with me throughout this process. I love you. 


\section{TABLE OF CONTENTS}

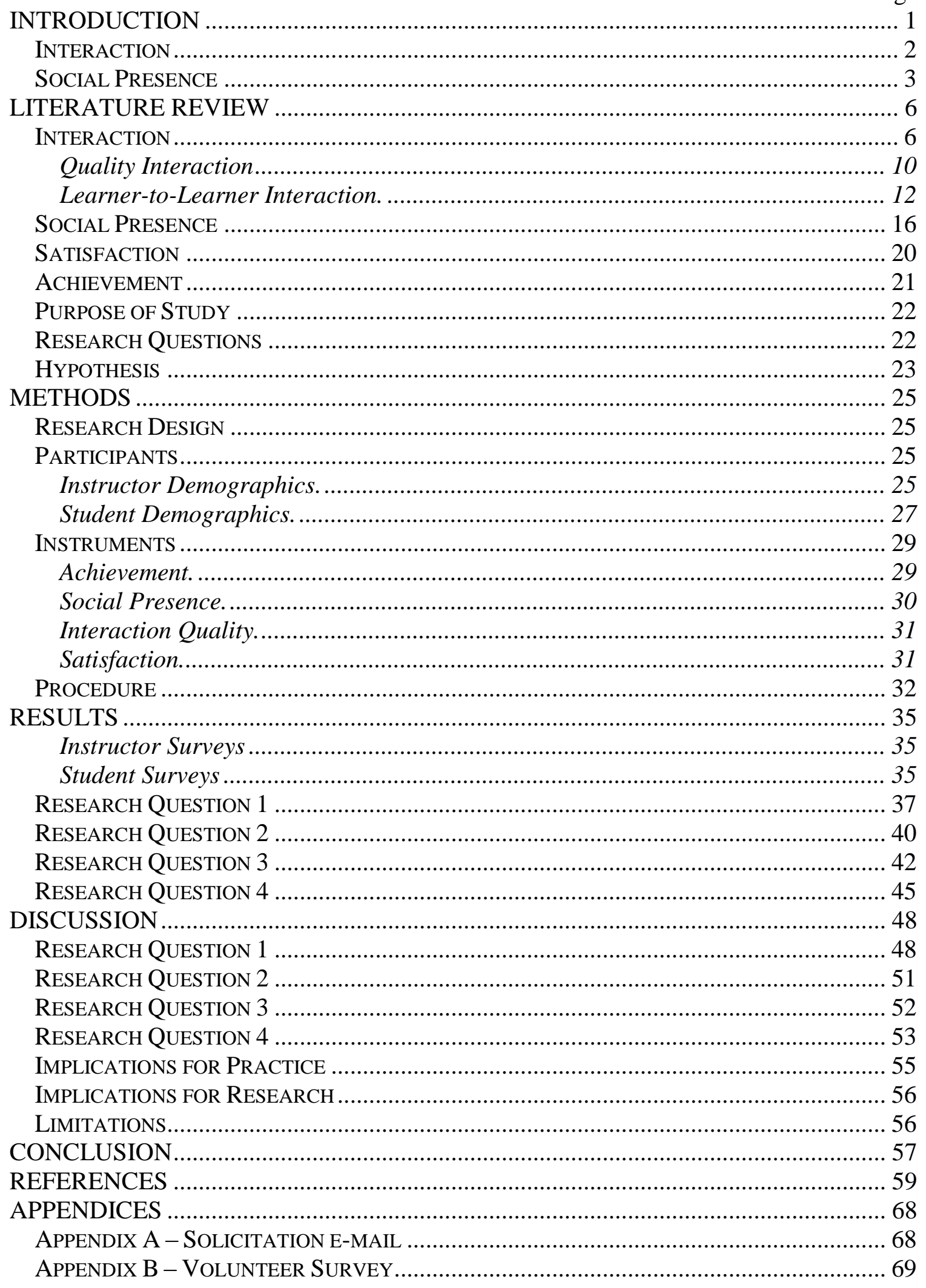




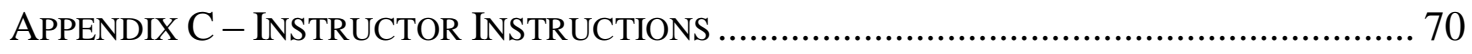

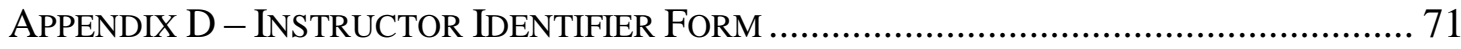

APPENDIX E - INSTRUCTOR GRADE REPORTING FORM........................................... 72

APPENDIX F - SOLO RUBRIC FOR INSTRUCTOR REFERENCE..................................... 72

APPENDIX G - INSTRUCTOR DEMOGRAPHIC SURVEY .......................................... 74

APPENDIX H - INSTRUCTOR SOCIAL PRESENCE SCALE............................................... 76

APPENDIX I - INSTRUCTOR INTERACTION QUALITY SCALE ...................................... 78

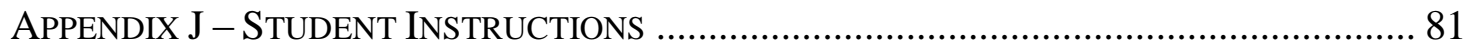

APPENDIX K - STUDENT DEMOGRAPHIC SURVEY ................................................. 83

APPENDIX L - STUDENT SOCIAL PRESENCE SCALE .............................................. 85

APPENDIX M - STUDENT INTERACTION QUALITY SCALE ........................................ 87

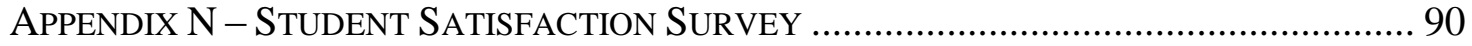

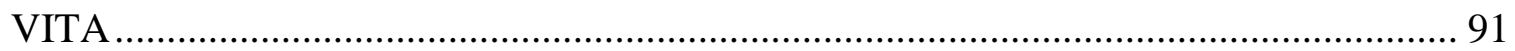




\section{CHAPTER 1 \\ INTRODUCTION}

Online teaching is an evolving field within education. As teaching and learning strategies are researched and developed, technologies used for online instruction are growing alongside them. Today, more than 20 million higher education students are enrolled in online courses or degree programs (Allen \& Seaman, 2013). This rapid growth has taken place in a short time considering face-to-face educational research and best practices have been compiled and reported for centuries.

The current focus of research regarding online courses concentrates on identifying effective design and delivery methodologies for online instruction. In order to identify effective design and delivery methodologies, researchers must detect problems or issues currently occurring in online learning. One persistent concern is that learners feel isolated or disconnected to the course, instructor, or other students (Johnson, 2006). Student isolation has been a concern since the inception of distance education. Moore (1989) defined this feeling of isolation as transactional distance. Transactional distance is defined as the cognitive distance which is defined as a psychological and communication space in which miscommunication can happen between instructors and learners in an educational setting (Bol \& Garner, 2011).

There are three interactive components that affect transactional distance: (a) dialog or interaction between the learners and instructors, (b) structure of the instructional program, and (c) autonomy or self-directedness of the learner (Moore, 1989). The lack of consensus of a definition of these terms is an issue that causes concern in generalizing the results of research studies and identifying proven effective design and delivery methods. 
Currently, these constructs have been analyzed using two major theoretical perspectives: interaction and social presence.

\section{Interaction}

Moore (1989) emphasized the need for a definition of interaction and defined three distinct types of interaction that should be considered when designing online learning: learner-to-learner, learner-to-content, and learner-to-instructor. Learner-tolearner interaction refers to interaction between individual students or among students working in small groups. Learner-to-content interaction refers to learner interactions with the course content to construct meaning, relate to prior knowledge, or to problem solve. Learner-to-instructor interaction refers to the instructor techniques used to stimulate and maintain the learner's interest in the course content. These types of interactions occur in face-to-face courses as well, but they may occur more organically without the necessity of deliberate planning required with online learning.

Hillman, Willis, and Gunawardena (1994) identified a fourth type defined as learner-to-interface interaction. This interaction refers to the interaction between the learner and the technology interface used to deliver the instruction. It is argued that learners need to acquire skills in order to participate effectively within the electronic environment. Fulford and Zhang (1993) defined vicarious interaction as an active observation of others' behaviors. However, for the purpose of this study, Moore's three types of interaction will be used to frame the research on interaction as they have received more research attention for impact on achievement.

The quality of the research methods employed in interaction studies has also been questioned (Bernard et al., 2009; Hyo-Jeong, 2010). Existing interaction research 
methods typically involve comparing types or amounts of interaction. Bernard et al. (2009) suggested that future research focus on the quality of interactions, as well as the instructional strategies that can aid in producing higher quality interactions. One focus of the current study is to identify quality learner-to-learner interaction instructional strategies. Much of the research regarding learner-to-learner interactions has been based upon social aspects of learning in face-to-face environments (Swan, 2003). Picciano (1998) suggests that research should relate online social concepts to actual learning and interactions.

\section{Social Presence}

There are competing definitions of social presence. Social presence was initially defined by Short, Williams, and Christie (1976) in the communication literature as the degree of salience of the other person in the interaction. They defined two concepts associated with this definition: intimacy and immediacy. Intimacy includes eye contact, physical proximity, and topic of conversation. Immediacy is the psychological distance between the communicator and recipient. Gunawardena (1995) defines social presence as when individuals are seen as "real" when communicating via media. Tu (2000) further defines social presence as having three dimensions: social context, online communication, and interactivity. Social contexts include task orientation, topics, recipients/social relationships, and social processes. Online communication refers to the attributes of the language used online, meaning that some level of computer communication literacy is required for learners to communicate effectively. Interactivity refers to the activities in which learners engage and the communication styles utilized. Conversely, Rafaeli (1988) defines social presence and interactivity separately; social 
presence is a subjective measure of the presence of others, while interactivity is the quality of communication or context.

Social presence is also one of the three constructs of the community of inquiry (CoI) framework, which is a widely used and researched model for online learning (Garrison, Anderson, \& Archer, 2000). Social presence is defined as the ability of the learners to project their personal characteristics into the community of inquiry. Rourke and Kanuka (2009) conducted a literature review of 252 CoI studies and found that only five studies measured student learning, of which all were subjective measures instead of objective measures. Their findings call into question the validity of the CoI framework to ensure deep and meaningful learning that the CoI framework developers claim.

For the purpose of this study, the Gunawardena (1995) definition of social presence will be used. Despite the different definitions, research shows that designing and encouraging a social presence amongst learners and the instructor can increase interaction, which in turn can increase learner satisfaction and theoretically performance (Gunawardena \& Zittle, 1997; Weinel, Bannert, Zumbach, Hoppe, \& Malzahn, 2011; Whipp \& Lorentz, 2009). However, it is unclear if a high level of social presence will produce higher quality interactions because many studies investigate the effects of quantity of interaction instead of quality (Bonnell, Katz, \& Every, 2009; Brewer \& Klein, 2004; Kiriakidis \& Parker, 2008).

The relationship between social presence and asynchronous online learner-tolearner interactions needs further investigation to determine effective methods for online instruction. Picciano (2002) suggests that interaction and presence can affect student performance independently, while Rourke and Kanuyka (2009) failed to find support in 
the CoI framework for promoting deep and meaningful learning (Bernard et al., 2009). This study will investigate the effects of learner-to-learner interaction techniques on social presence, learner achievement, and satisfaction in online undergraduate asynchronous courses. This study will also investigate how the degree of social presence effects on interaction quality, learner achievement, and satisfaction. 


\section{CHAPTER 2}

\section{LITERATURE REVIEW}

This literature review is presented in four sections. Each section represents topics and sub-topics that were investigated in this research study. The topics are interaction, social presence, satisfaction, and achievement. Interaction includes subtopics of learnerto-learner interactions and interaction quality. Each section presents relevant literature on how each topic relates to the other topics in the context of higher education and online teaching. The topics and sub-topics were selected to frame the literature review because they represent the independent and dependent variables investigated in this research study.

\section{Interaction}

There are multiple definitions of the term interaction in regards to distance learning. However, regardless of how interaction is defined or operationalized, it is widely believed that interaction has positive effects on learner satisfaction in online courses. Distance educators have advocated an increase in learner-to-learner interactions (Davidson-Shivers, 2009). Many studies report that more interaction yields higher satisfaction implying that more interaction leads to more effective learning online (Fulford \& Zhang, 1993; Kuo, Walker, Belland, \& Schroder, 2013; Picciano, 2002). However, other researchers disagree with this overly positive view of interaction and suggest it be further examined with more rigorous methods such as experiments comparing instructional methods that include measures of achievement (Moore, 1989; So \& Brush, 2004; Wagner, 1994). Others suggest that more interaction does not ensure higher achievement. They argue that research should turn attention to identifying the 
quality of interaction methods instead of assessing quantity of interaction taking place (Bernard et al., 2009; Grandzol \& Grandzol, 2010; Tu \& McIsaac, 2002).

Researchers are particularly interested in the effects of interaction and achievement in online courses. For instance, Jung, Choi, Lim, and Leem (2002) conducted a study investigating effects of different types of interaction on achievement, satisfaction, and participation. There were 124 undergraduate participants from three courses. The three courses had the same content, but required the learners to participate in one of three types of interaction: (a) academic, (b) collaborative, or (c) social. The academic group served as the control group and only had interaction with the instructor for content related matters. The collaborative group was given the opportunity or choice to participate in one or more discussion activities. The social group was provided various kinds of interpersonal and social feedback from the instructor in addition to content related communication. The social interaction group had higher achievement than the other two groups. Achievement was measured through an average of grades given by the instructor over the course of five assignments. The collaborative group expressed the highest level of satisfaction regarding the learning experience. The social and collaborative groups interacted with each other more than the academic control group. This finding suggests that learner-to-learner interaction increases satisfaction while learner-to-instructor interaction that includes academic and social communications increases achievement. However, the authors of this study implied achievement was affected, but no objective evidence was provided.

An additional study that included interaction effects on achievement was conducted by Taylor (2014). This study investigated the relationship between the three 
types on interaction and academic success in asynchronous online courses by analyzing archived tracking data from a learning management system during the first two weeks of courses. The data set included 1,703 students and 200 courses. A regression analysis was used to investigate the relationships among variables. Student-to-student interaction was measured by number of posts made to discussion forums. Student-to-instructor interaction was measured by number of discussion board posts and instructor e-mails. Student-to-content interaction was the total number of pages accessed. Academic success was measured as course grades and placed into one of three categories: successful completers (A, B, or C), low score completers (D or F), and non-completers (students who did not complete course). The multinomial logistic regression was statistically significant that indicated predictors are distinguishable between the three types of interactions. The results revealed that the quantity student-to-student interaction served as the strongest predictor of achievement followed by student-to-content interaction. This study suggests that more student-to-student interaction will increase achievement, but measurements were quantity of interactions and did not address the level of quality of interactions nor if any interaction occurred.

In regards to interaction effects on satisfaction, Kuo, Walker, Schroder, and Belland (2014) tested a regression model using hierarchical linear modeling for student satisfaction using the three types of interaction as well as Internet self-efficacy and selfregulated learning as a student characteristic. A survey that measured each of the five predictors was completed by 180 undergraduate education students in 26 courses. The analysis showed that only learner-to-instructor and learner-to-content interactions significantly predicted learner satisfaction. The researchers suggested that content should 
be presented in an organized way and easily accessible. They also suggested that instructors regularly post in discussion boards and respond to questions in a timely manner to increase interaction with students. The Likert-type items measuring learn-tolearner and learner-to-instructor interactions addressed quantity of interactions but not quality of interactions.

A meta-analysis on interaction conducted by Bernard et al. (2009) sought to determine the effects of Moore's types of interaction on achievement and satisfaction. They concluded that stronger course design features made a substantial difference in achievement and engagement in online learning. Increased effect sizes were found with the student-content interaction with the combinations of student-content plus studentstudent interactions and student-content plus student-instructor interactions. These findings imply that the learner-to-learner and the learner-to-instructor interactions in an online course should be designed well and have a strong link to the course content. The findings suggest that the availability of interaction is related to increased learning; however, the findings do not show whether interactivity increases learning. It was suggested that future research studies focus on instructional designs that foster quality interactions.

This study focused on the learner-to-learner interactions, since they involve multiple individuals who are communicating via technology. This aspect is important when investigating social presence. The learner-to-content interaction is important to consider when designing courses, but is individualistic and is typically defined by existing reading materials such as a textbook. The learner-to-instructor interaction is also 
important, but is often a one-on-one interaction instead of a group interaction. Thus, this study will focus on the learner-to-learner interactions.

\section{Quality Interaction}

As evidenced in the previous section much of the research on interaction is concerned with the quantity of interaction rather than the quality of interaction. Quality interaction is operationalized by Roblyer \& Wiencke (2003) into five elements: instructional design, interactivity of technology resources, student engagement, instructor engagement, and social rapport. The design of the instructional activity needs to be purposeful and follow methodologies suggested by instructional design theories and models. The technologies used should be well matched with the design of the instructional activity. Students should engage in the instructional activity, which would be evidenced by the amount of interaction, the thoughtfulness and details of the interaction, how well the interactions are developed, and whether interactions take place voluntarily or when required. Instructors should also be engaged in the instructional activity that could be evidenced by interacting consistently, quickly, and providing helpful and useful feedback. Social rapport should increase throughout the instructional activity. Their research has yielded a rubric that measures interaction quality with subscales of these five categories. This rubric will be used to measure interaction quality from the student and instructor perspective. The high interactive qualities for each element are defined in the following list.

- Social/rapport-building designs for interaction- In addition to providing for exchanges of personal information and encouraging student-student and instructor-student interaction, the instructor provides ongoing course 
structures designed to promote social rapport among students and instructor.

- Instructional designs for interaction- In addition to the requiring students to communicate with the instructor, instructional activities require students to develop products by working together cooperatively (e.g., in pairs or small groups) and share results and feedback with other groups in the class.

- Interactivity of technology resources- In addition to technologies to allow two-way exchanges of text information, visual technologies such as twoway video or videoconferencing technologies allow synchronous voice \& visual communications between instructor and students and among students.

- Evidence of learner engagement - By the end of the assignment/activity, all or nearly all students (90-100\%) are both replying to and initiating messages, both when required and voluntarily; messages are detailed, responsive to topics, and are well-developed communications.

- Evidence of instructor engagement Instructor responds to all student queries; responses are always prompt, that is, within 24 hours; feedback always offers detailed analysis of student work and suggestions for improvement, along with additional hints and information to supplement learning.

One study that applied this rubric to assess the quality of interaction effects on achievement and satisfaction was conducted by Alderman (2005). They designed a 
course with a high level of collaborative interaction. At the conclusion of the course, the Roblyer \& Wiencke's (2003) rubric was applied to benchmark types and measure levels of interaction. Learners were surveyed regarding their perceptions of achievement and satisfaction. Focus groups were also used to help explain the results in more depth. The conclusion was that learners felt that quality interaction was an essential contributor to perceived achievement and satisfaction. This study involved a very small convenience sample of 12 learners and measured perceived achievement. More empirical evidence is needed to be able to generalize this conclusion.

\section{Learner-to-Learner Interaction.}

Learner-to-learner interaction can occur between one learner and another, between small groups of students, or between all the students in the course. Typically, in asynchronous online learning, this type of interaction occurs asynchronously via e-mail, a discussion board, or synchronously through a virtual classroom or instant messenger. Instructors usually encourage or require this interaction via assignments, discussion prompts, or group projects, and may include it as part of the course grade. Palloff and Pratt (2001) suggested that collaborative projects might lessen the learners' sense of isolation and promote social presence. Conversely, Thurmond, Wambach, Connors, and Frey (2002) found that learners who were required to participate in team or group assignments reported less satisfaction with the course. The stated reason for this dissatisfaction was due to the challenge of completing the assignments without face-toface contact with group members. Bol and Garner (2011) argue that learners may selfselect distance versus face-to-face depending on learner preferences. However, this argument needs empirical confirmation. 
Much of the research regarding learner-to-learner interactions in asynchronous online learning is concerned with the amount of interaction, instead of how the interaction occurs and whether that interaction is of high quality (Bonnell, Katz, \& Every, 2009; Brewer \& Klein, 2004; Kiriakidis \& Parker, 2008). This type of research is limited because it does not enable designers to identify best practices for designing quality interactions. In addition, the authors report that learner-to-learner interaction increases learner satisfaction, which may further suggest an increase in achievement (Oncu \& Ozdilek, 2013; Stein, Wanstreet, Calvin, Overtoom, \& Wheaton, 2005). This conclusion requires an assumption that high learner satisfaction will result in increased achievement. However, evidence that is more empirical is required to make this generalization.

One proxy measure for satisfaction may be sense of community to interactions. Shackelford and Maxwell (2012) investigated which learner-to-learner interactions were most predictive of sense of community in online learning by surveying 381 graduate students. The survey included demographic information, a sense of community scale (Rovai, 2002), and an interaction survey. The interaction survey was generated from a literature review that identified nine interactions that contributed to sense of community. The nine interactions were: introduction, ice-breakers, online discussions (entire class), online discussions (small group), social communication, collaborative group projects, peer teaching, exchanging resources, and contributing personal experiences. The results showed that all nine interactions had a positive correlation with sense of community. The top contributors were introductions, collaborative group projects, and contributing personal experiences. These findings suggest that learners should have the opportunity to interact socially and academically to build course community. However, this study did 
not address whether these interaction techniques will increase learner achievement or whether these techniques produce quality interactions.

An additional study that investigated whether student-to-student and student-toinstructor interactions were associated with student's perceived learning and satisfaction was conducted by Sher (2009). Two Hundred and eight undergraduate students in 30 course sections were surveyed. All measures were questionnaires featuring Likert-type scales. Results showed that both student-to-instructor interaction and student-to-student interaction were significantly associated with perceived learning and satisfaction. This finding implies that incorporating student-to-student and student-to-instructor interactions will increase perceived learning and satisfaction, but the findings did not address best practices for designing and implementing those interactions. One shortcoming of prior research is the use of subjective measures (Rourke \& Kanuka, 2009) rather than objectives measures of achievement that would provide evidence of the effectiveness of the interactions.

A meta-analysis was conducted on learner-to-learner interaction literature by Borokhovski, Tamim, Bernard, Abrami and Sokolovskaya (2012). A subset of studies included in the meta-analysis conducted by Bernard et al. (2009) on all three types of interaction literature was used. This subset of literature included studies in which learnerto-learner interactions in the experimental group were more prevalent than the control groups. There were 32 studies yielding 36 independent effect sizes based on 3,634 participants. Borokhovski et al. (2012) focused specifically on learner-to-learner interactions with the intention of identifying the types of learner-to-learner interactions that were more effective. 
The analysis yielded two categories of student-to-student interaction treatments: designed interactions and contextual interactions. Designed interactions are instructional activities that are specifically designed and implemented to provide opportunities for students to work together. Cooperative learning and collaborative learning activities were provided as examples of designed interactions. These types of activities require the learners to interact with one another while completing an activity or an assignment. Contextual interactions provide options and alternatives for the students to interact with one another, but have no explicit instructional intent. Discussion boards in which students were encouraged to participate and account for others' opinions were given as an example of contextual interactions. A more specific example of this type of interaction would be a discussion board in which a broad prompt is provided with little or np guidance provided on how to interact or facilitate the discussion.

The mixed effects model was used to analyze the different effect sizes between designed interactions and contextual interactions. The results suggested designed interactions had more of an effect on achievement than contextual interactions, with a positive weighted effect size of $\mathrm{g}+=0.38$ which is a moderate effect size. Lou, Abrami, and d'Apollonia (2001) found similar results investigating small groups in classroom contexts. There were variations in the designed interactions, but three promising tactics were identified: (a) role-based scenarios, (b) scaffolding by establishing rules and procedures of interaction, (c) monitoring and adjusting interaction by providing meaningful and timely feedback, both from instructor and peers. It was recommended that designers consider four elements when designing interaction to produce higher quality interactions: (a) positive interdependence; (b) individual accountability; (c) 
promotive interactions; and (d) elaborate explanations. Positive interdependence refers to the learner's perception of working together is individually and collectively beneficial and that success depends on participation of every group member. Individual accountability refers to the belief that each learner will be held accountable for their performance. Promotive interactions refers to the learner's belief that ongoing interactions are required for success. Elaborate explanations refers to effective collaboration with a focus on encouraging understanding. Lou et al. (2001) also suggested that a promising approach to increasing learner performance via interactions is to explicitly plan for cooperative or collaborative activities in the design of course activities.

\section{Social Presence}

The term social presence was coined by Short et al. (1976) when the social presence theory was developed to explain the effect of telecommunications media have on communications. However, psychologists and sociologists previously researched the idea of social presence prior to the term's existence. Mehrabian (1969) conducted a study on the effects of nonverbal behaviors on the communicator's attitude toward the responsiveness of the message receiver. The nonverbal cues included posture, position, movement, facial, and implicit verbal cues. The findings indicated that non-verbal cues were significant indicators of the communicator's attitude. For example, in a study by Argyle and Dean (1965) aspects of the eye contact and equilibrium for distance were examined. Eye contact was defined as an aspect of intimacy during social interaction. Intimacy also included physical proximity, intimacy of topic, amount of smiling, etc. The researchers tested pairs of participant's eye-contact levels at various distances during a 
three-minute conversation in order to determine an equilibrium distance for optimal eye contact. The results revealed that eye contact was linked to special proximity. The larger the distance between the participants resulted in decreased levels of eye contact. Although this study was not conducted regarding online learning it does reveal implications for design decisions regarding online interactions and social presence since nonverbal communications are more challenging to achieve online.

Social presence theory (Short et al., 1976) equates social presence to different forms of media. For example, video has a higher degree of social presence and audio has a lower degree of social presence because of the lack of non-verbal and relational clues. They argued that face-to-face interaction has the highest degree of social presence because more verbal and non-verbal signals are transmitted which is perceived as more sociable, warm, and sensitive.

Early research in online education involving social presence and online learning focused on text-based communications because online learning technology was limited to text-based communication. Researchers argued that learners were able to project themselves as "real" into text discussions using emoticons, stories, and humor (Swan, 2003; Swan \& Shih, 2005). As online learning technologies have evolved, so has social presence research. Currently, social presence is a central concept in online learning and appears as a key component in several online learning frameworks such as CoI. The focus of this research has turned away from technological medium and onto people (Lowenthal, 2010). Researchers have found that the level of social presence in online learning can differ from one learner to another. That brings into question whether the characteristics of the technology or the individuals that affect social presence 
(Gunawardena and Zittle, 1997; Tu, 2002). Mykota and Duncan (2007) found that number of online courses taken and level of technical proficiency were significant predictors of a sense of social presence.

Social presence has also been defined to include several concepts and dimensions. Initially, Short et al. (1976) included the concepts of intimacy and immediacy. Similar to the definitions studied by Argyle and Dean (1965) intimacy depends on factors such as physical distance, eye contact, smiling and personal topics. According to Wiener and Mehbrabian (1968), Immediacy is the psychological distance between the communicators. $\mathrm{Tu}$ (2000) further conceptualized social presence adding the three dimensions of social context, online communication, and interactivity.

Social presence has been found to be correlated with several variables such as learner satisfaction, collaborative learning, development of community, and perceived learning. So and Brush (2008) conducted a mixed method study that examined learner's perceived levels of collaborative learning, social presence and satisfaction in a blended learning environment with 48 graduate students participating in a collaborative group project. The results showed perceived collaboration had statistically positive relationships with social presence and satisfaction. Rovai (2001) analyzed sense of classroom community with 20 adult learners in a five-week graduate course that was delivered fully online asynchronously. Sense of classroom community was measured with a classroom community scale at the beginning and end of the course. Findings showed that sense of classroom community significantly grew over the duration of the course. Caspi and Blau (2008) tested the correlation between three concepts of social presence and different aspects of perceived learning with 659 students completing a questionnaire. The three 
aspects of social presence tested were a subjective quality of a medium that determines the quality of communication and perception of others, self-projection onto the group, and identification with the group. The results indicated that perceived learning positively correlated with self-projection and social identification, but not with perception of others.

Research has suggested that social presence is strongly related to level of interaction (Gunawardena \& Zittle, 1995; Tu, 2000; Tu \& McIsaac, 2002). The relationship is positively correlated, meaning that as social presence increases then the level of interaction also increases and vice versa. Gunawardena and Zittle (1995) used a regression analysis to investigate social presence as a predictor of learning satisfaction in a text based learning environment. The analysis converged on a three-predictor model that accounted for $68 \%$ of the variance: social presence, student perceptions of having an equal opportunity to participate, and technical skills. Social presence accounted for $60 \%$ of that variance indicating that it was a very strong predictor of learning satisfaction. $\mathrm{Tu}$ (2000) examined the relationship between social presence theory and social learning theory in computer-mediated communication (CMC) and determined that social interaction was fundamental to the explanation of this relationship. Tu and McIsaac (2002) examined dimensions of social presence using mixed methods. The questionnaires measure level of social presence were sent to 51 students enrolled in a graduate level course. The survey contained 30 Likert-type items: 17 measuring social presence and 13 measuring privacy. Participants were observed in a computer laboratory and interviewed in formal and informal settings. A document analysis was also conducted on all of the course correspondence. Three dimensions of social presence emerged as important elements to consider when establishing a sense of community: social context, online 
communication, and interactivity. An increased level of social presence indicated an increased level of interaction.

The results of these studies on social presence imply that social presence increases with interactions between the learners and the instructor. However, these findings do not address whether more interaction means the interaction is of high quality. It is not known whether a higher social presence will affect achievement or produce quality interactions. The best strategies for generating social presence that will best predict achievement in online learning have also yet to be identified. Implications for future research mentioned by Lowenthal (2010) advise multiple and mixed methods studies that focus on the socially situated and contextual nature of social presence in order to identify best practices.

\section{Satisfaction}

Research has shown that social presence is a predictor of learner satisfaction. Gunawardena and Zittle (1997) conducted a study to determine how effective social presence is as a predictor of overall learner satisfaction in a text-based medium. The results revealed that social presence and technical skills accounted for $68 \%$ of the variance. Social presence alone accounted for $60 \%$ of that variance indicating that it may be a strong predictor of satisfaction. A social presence scale based on the concept of immediacy and a satisfaction scale was developed and validated as part of this study. These are the scales used to measure social presence and satisfaction in this study.

More recently, Horzum (2015) validated the relationship of interaction, social presence, and satisfaction using structured equation modeling with 205 university students. The findings showed that online students' social presence was predicted 
positively by level of interaction and online learner satisfaction by level of social presence. Therefore, students are most satisfied when their social presence is high. Methods on how to increase student social presence in order to increase satisfaction were not reported.

\section{Achievement}

There is little evidence that increased interaction or social presence affects achievement. Wei, Pang, and Chou (2015) investigated how interactivity affects learner achievement by analyzing course management access logs and surveying 381 undergraduate students. Results indicated that more interactivity had mediated effects on learner performance. This study is similar to others mentioned previously that show that increased quantity of interaction also increases achievement. How these interactions are designed or if they are of high quality is unclear.

Quality interaction effects on social presence and achievement was examined by Kožuh, Jeremić, Sarjaš, Bele, Devedžić, and Debevc (2015). They analyzed the relationships between intensity of social interactions, quality of social interactions, academic success, and social presence using surveys and access logs of 62 undergraduate engineering students. The results showed that the intensity and quality of social interactions were connected to student success and that social presence had no connection to academic success. The quality of the social interactions was assessed by the instructor and the academic success rated by the grade given by the instructor. These may not be reliable or valid measures and the connection between social interactions and achievement was not explained. 


\section{Purpose of Study}

The relationships between learner-to-learner interactions, achievement, social presence, and satisfaction in online learning have varying degrees of strength according to the research. The link between level of interaction, social presence, and satisfaction is strong. However, the link between interaction and achievement is weak because much of the research on learner-to-learner interaction focuses on quantity of interaction instead of quality, but there has been indication that quality interactions have more effect on achievement, satisfaction, and social presence. More evidence is needed to clarify relationships among these variables and to identify best practices for designing learnerto-learner interactions to increase achievement, level of social presence, and learner satisfaction.

The purpose of this study was to identify effective learner-to-learner interaction techniques that increase learner social presence, satisfaction and achievement. Achievement was measured in three ways: an assignment grade, a course grade and a Structured observed learning outcome (SOLO) taxonomy measure (Biggs \&Collis, 1982). The SOLO taxonomy describes five complexity levels of learner understanding of a topic. The levels are: pre-structural, uni-structural, multi-structural, relational, and extended abstract. A learner at the lowest pre-structural level as acquired bits of information with no connection between the bits. A learner at the highest extended abstract level is making connections between the bits of information in the given subject area and able to extend or apply that information to a new context or subject.

\section{Research Questions}

This study sought to answer the following research questions. 
1) Does the type of learner-to-learner (designed or contextual) interaction affect achievement, social presence, and satisfaction in fully online asynchronous undergraduate courses?

2) Does the level of instructor social presence affect achievement, quality interaction, and satisfaction in fully online asynchronous undergraduate courses?

3) Does the level of learner social presence affect quality of learner-to-learner interactions, achievement, and satisfaction in fully online asynchronous undergraduate courses?

4) Does the quality of interaction affect level of social presence, achievement, and satisfaction?

\section{Hypothesis}

The hypothesis for research question one was that designed interactions would have higher levels of achievement, social presence, and leaner satisfaction. This result supports Borokhovski et.al. (2012) meta-analysis conclusion regarding designed interactions. The hypothesis for research question two was that higher levels of instructor social presence would produce higher achievement, interaction quality, and learner satisfaction. The hypothesis for research question three was that higher levels of social presence would produce higher quality interactions, achievement levels, and learning satisfaction. The result of these two hypothesis supports So and Brush's (2008) conclusion regarding social presence. The hypothesis for research question four was that higher quality interactions would produce higher-level social presence, achievement, and 
satisfaction. This result supports Alderman's (2005) conclusion regarding quality interaction. 


\section{CHAPTER 3}

\section{METHODS}

\section{Research Design}

This non-experimental, comparative study investigated the strategies used for learner-to-learner interactions effects on achievement, social presence, and satisfaction. This study also investigated the level of social presence effects on interaction, achievement and satisfaction. A portion of 17 fully online asynchronous undergraduate courses was analyzed.

Surveys measuring social presence and interaction quality for instructors and students were the same, except for slight modifications to address the appropriate audience. A survey measuring learning satisfaction was only administered to the students. Achievement measures were collected via three performance ratings from the instructors. The surveys and forms were comprised of several instruments measuring several constructs described in the following sections.

\section{Participants}

The participants in this study were 15 volunteer instructors and 227 students in 17 fully online undergraduate asynchronous courses of varying subjects at a mid-sized southeastern university. The following tables present the faculty and student demographics.

\section{Instructor Demographics.}

The researcher compiled all instructor and student survey data and matched the student survey data to collected achievement data to begin the analysis process. All volunteer instructors, regardless of whether students completed surveys, completed the 
instructor survey. Some faculty volunteers had no student participation. Therefore, more instructors completed the survey compared to the number of instructors are included in the final student data set. However, since the survey was anonymous, it was impossible to separate instructors that had student data from those that did not. Hence, these results provide general information regarding all the volunteer instructors. Table 1 summarizes the volunteer instructor demographic information. A majority of the instructors were full-time lecturers who have taught more than 10 online courses. They are comfortable with computers and most are from health science field. Many of the instructors have had training in instructional design and online teaching methodology.

Table 1

Instructor Demographics

\begin{tabular}{llcc}
\hline Question & Choices & Frequency & Percentage \\
\hline What is the subject area of your course? & Science & 6 & 20.7 \\
& Health Science & 10 & 34.5 \\
& Education & 4 & 13.8 \\
& Business & 2 & 6.9 \\
& Cultural Arts & 7 & 24.1 \\
\hline Select your age range. & $20-30$ & 8 & 27.6 \\
& $30-40$ & 6 & 20.7 \\
& $40-50$ & 5 & 17.2 \\
& 50-60 & 8 & 27.6 \\
& Over 60 & 2 & 6.9 \\
\hline Select your gender. & Male & 10 & 34.5 \\
& Female & 19 & 65.5 \\
\hline What is your Classification? & Professor & 6 & 20.7 \\
& Associate Professor & 4 & 13.8 \\
& Assistant Professor & 3 & 10.3 \\
& Full Time Lecturer & 11 & 37.9 \\
What is your level of computer skill? & Part Time Lecturer & 5 & 17.2 \\
\hline & Minimal Knowledge & 0 & 0 \\
& Some Knowledge & 3 & 10.3 \\
& Comfortable & 22 & 75.9 \\
& Advanced & 4 & 13.8 \\
\hline Approximately how many online classes & 0-2 & 6 & 20.7 \\
& & 4 & 13.8 \\
have you taught? & 3-4 & 6 & 20.7 \\
& 5-10 & 13 & 44.8 \\
\hline
\end{tabular}




\begin{tabular}{lccc}
\hline $\begin{array}{l}\text { Have you received any training in online } \\
\text { teaching methodology? }\end{array}$ & Yes & 20 & 69.0 \\
& No & 9 & 31.0 \\
\hline $\begin{array}{l}\text { Have you ever received any training in } \\
\text { instructional design? }\end{array}$ & Yes & 17 & 58.6 \\
& No & 12 & 41.4 \\
\hline
\end{tabular}

\section{Student Demographics.}

Table 2 summarizes the student survey demographic information. A majority of the students are 18-24-year-old, full-time female students in the health science field. Many of the students are employed full-time and full-time students. Most of the students are comfortable with computers and have taken more than five online courses. This demographic information is consistent with the institutional demographic information since the largest online program at this institution is a program for working registered nurses earning their bachelor's degree.

\section{Table 2}

Student Demographics

\begin{tabular}{llcc}
\hline Question & Choices & Frequency & Percentage \\
\hline What is the subject area of your course? & Science & 43 & 18.9 \\
& Health Science & 142 & 62.6 \\
& Education & 16 & 7.0 \\
& Business & 2 & .9 \\
& Cultural Arts & 24 & 10.6 \\
\hline Select your age range. & $15-17$ & 0 & 0 \\
& $18-24$ & 139 & 61.2 \\
& $25-40$ & 54 & 23.8 \\
& $40-50$ & 21 & 9.3 \\
& $50-60$ & 13 & 5.7 \\
& Over 60 & 0 & 0 \\
\hline Select your gender. & Male & 32 & 14.1 \\
& Female & 195 & 85.9 \\
\hline What is your current student & Freshman & 2 & .9 \\
classification? & & & \\
& Sophomore & 5 & 2.2 \\
& Junior & 50 & 22.0 \\
& Senior & 117 & 51.5 \\
& Non-Traditional & 53 & 23.3
\end{tabular}




\begin{tabular}{llcc}
\hline What is your current student status? & Part-Time & 59 & 26.0 \\
& Full Time & 168 & 74.0 \\
\hline What is your current job status? & Unemployed & 42 & 18.5 \\
& Part time employee & 76 & 33.5 \\
& Full time employee & 109.0 & 48.0 \\
\hline What is your level of computer skill? & Minimal Knowledge & 0 & 0 \\
& Some Knowledge & 20 & 8.8 \\
& Comfortable & 173 & 76.2 \\
& Advanced & 34 & 15 \\
\hline Approximately how many online classes & $0-2$ & 19 & 8.4 \\
have you taken? & & & \\
& $3-4$ & 42 & 18.5 \\
& $5-10$ & 88 & 38.8 \\
& More than 10 & 78 & 34.4 \\
\hline
\end{tabular}

Faculty volunteered their courses for participation via electronic survey deployed by the distance learning office (Appendices A and B). This survey requested the faculty to volunteer one fully online asynchronous course and, more specifically, one single graded assignment or activity within that course. Faculty were informed in the solicitation e-mail that the selected assignment/activity must have learner-to-learner interaction during the duration of the assignment/activity and that the assignment/activity must be graded. Incentives were offered to faculty and students for participation. Faculty received a brief paper regarding best practice findings from the results of the study. Students were offered the opportunity to enter a prize drawing for five headsets with microphones that can be used for online learning.

Participant's names remained anonymous, but every participant generated an identification number based on several questions to match the data from each data collection for statistical analysis. This identification number was also used to match each student's participant survey data to the achievement data. Demographic data such as age, gender, number of online course taken or taught, status (student or instructor), and 
technology experience was collected in an initial survey when the participants were informed about data protection and anonymity. Instructors were provided with information regarding data protections and anonymity when they volunteered the courses to be part of the study at the beginning of the course.

\section{Instruments}

\section{Achievement.}

Instructors provided the participating students' grades on the assignment or activity that they identified when they volunteered the course. In addition to the assignment/activity grade, the final course grade was also reported. As an additional measure of achievement the instructors were asked to provide a rating of the for each consenting participant's understanding of the assignment/activity on a scale of 1 to 5 using the Structure of the Observed Learning Outcomes (SOLO) taxonomy (Briggs \& Collis, 1982). This rating controlled for various types of assignments and activities used across courses (Appendix F). All achievement measures were reported associated with the students generated research identification number to ensure anonymity. .

The SOLO taxonomy, which has strong face validity, describes increasing complexities of a learners understanding of a topic. The five levels of the taxonomy are: pre-structural, uni-structural, multi-structural, relational, and extended abstract. Prestructural is the lowest level and represents when the learner has missed the point of the assignment/activity or has not approached it appropriately. Uni-structural is the next level in which the learner simply focuses on a single aspect of the assignment/activity. Multistructural is the next level in which the learner focuses on several aspects of the assignment/activity independently. Relational is the next level in which the learner has 
integrated all aspects of the assignment/activity as a coherent whole. Extended abstract is the highest level in which the learner can generalize the coherent whole to a new assignment/activity. This rating reflects not only level of achievement but also the quality of learning that was achieved.

\section{Social Presence.}

A unidimensional social presence scale developed by Gunawardena and Zittle (1997) was used to measure learner social presence. The language on the survey was slightly changed to reflect the terminology appropriate for this study. This scale contains 14 Likert-type items with rating scale options ranging from 1-5. A score of $1=$ strongly disagree, 2 disagree, $3=$ uncertain, $4=$ agree, and $5=$ strongly agree. Reliability was reported as a Cronbach Alpha of .88. Content validity of the Social Presence Scale was assessed by through a bivariate correlational analysis comparing it with six selected bipolar social indicators used by Short et al. (1976) to measure the concept of immediacy. The positive polar ends of the social indicators were: immediate, interactive, personal, sensitive, social, and warm. Correlation coefficients were reported as .52-.87 between the bi-polar items and the Social Presence scale, which suggests that the Social Presence Scale measures the intended social presence parameters.

Instructor's level of social presence was measured by an instructor social presence scale developed by Pollard, Minor and Swanson (2014). This scale contains 10 Likerttype items with rating scale options ranging from 1-5. A score of $1=$ strongly disagree, 2 $=$ disagree 4=agree, and 5=strongly agree. Reliability was reported as a Cronbach's Alpha of .971. The unrotated factor loadings of these items were .81-.93 suggesting that all items load upon a single factor. 


\section{Interaction Quality.}

Roblyer and Wiencke's (2004) rubric for assessing interactive qualities (RAIQ) in distance courses was used. This rubric contains five separate elements: (1) social/rapport designs for interaction, (2) instructional designs for interaction, (3) interactivity of technology resources, (4) evidence of learner engagement, and (5) evidence of instructor engagement. The maximum score for each element is 5 points resulting in a maximum total score of 25 points. The authors estimated the reliability using Chronbach Alpha. The Chronbach Alpha coefficients for each course were as follows: .88 (100\% asynchronous), .64 (80\% asynchronous/20\% face-to-face), .93 (50\% asynchronous, $40 \%$ synchronous and $10 \%$ face-to-face) and $.95(90 \%$ asynchronous and $10 \%$ face-to-face). These results indicated high consistency of ratings across student raters. Pearson correlations were calculated to across four courses determine the rubric's concurrent validity. All correlations were found to be significant. The total evaluation score and total rubric score correlation was reported at .64 (Roblyer \& Wienke, 2004).

\section{Satisfaction.}

A unidimensional satisfaction survey was used to measure each student's satisfaction of learning in the study course (Gunawardena \& Zittle, 1997). Two of the original items of the survey were omitted because they were not pertinent to this study. The rest of the items were edited to reflect the language of this study. Reliability was reported as .87 using Cronbach's Alpha. Validity data was not presented. This survey was also disseminated electronically and administered at the end of the assignment/activity. This survey is an eight item, 5-point Likert-type instrument designed to measure satisfaction. Rating scale options range from $1=$ strongly disagree, $2=$ disagree, $3=$ 
uncertain, $4=$ agree, to $5=$ strongly agree. The cumulative scores range from 0 to 40 with high scores indicating more satisfaction of learning.

\section{Procedure}

A solicitation e-mail was sent to all fully online asynchronous faculty members teaching in the summer I, summer II, and fall semesters from the institution's distance learning office (Appendix A). This e-mail briefly described the study and requested faculty to participate in the study and to volunteer a particular graded assignment or activity within their course to be reviewed that required learners to interact with one another. The faculty members that agreed to participate in the study also allowed the researcher to have access to the course materials that were housed within the institution's learning management system. The researcher and a co-rater reviewed these materials in order to identify the interaction groups for each assignment or activity. The researcher and the co-rater rated the instructions for the activity to place each assignment or activity into one of two categories: designed interaction group or contextual interaction group. Decisions were made solely on explicit evidence of collaborative/cooperative instructional activities/assignments. The researcher and co-rater rated each assignment/activity using a scale of zero through five with zero being the no evidence of collaborative/cooperative intent in the instructions and five being very explicit collaborative/cooperative intent in the instructions. The interrater reliability for the raters was Kappa $=0.69$. Assignments/activities rating an average of 3-5 were placed in the designed interaction group and assignment/activities rating 0-2 were placed in the contextual interaction group. There were 7 faculty and 150 students in the designed interaction group and 9 faculty and 77 students in the contextual interaction group. One 
faculty member volunteered three courses, one for each semester of the data collection. Two of the courses were in the contextual interaction group and one was in the designed interaction group. All volunteered assignments/activities were evaluated for inclusion in the data set. Any volunteered assignment/activity that had no learner-to-learner interaction was excluded from the data set.

The faculty members were provided with a notification document outlining the confidentiality protections of data collected (Appendix C). They then completed a survey, which included the social presence scales (Appendix $\mathrm{H}$ ) and the interaction quality rubric (Appendix I) before implementation of the assignment or activity. The survey language was modified to suit the appropriate audience. This modification allowed the researcher to collect data regarding the instructor's intent or design of the interactions within the volunteered assignment or activity. The assignments or activities were then implemented as designed by the instructors.

The students read a notification document outlining the confidentiality protections of data collected prior to beginning the assignment or activity (Appendix $\mathbf{J}$ ). The survey for the learners, which included the social presence scale (Appendix L), the interaction quality rubric (Appendix M), and the satisfaction scale (Appendix N) were deployed at the completion of the assignment/activity with language appropriate for that audience. Instructors provided the assignment or activity and end of course grades to the researcher at the completion of the course (Appendix E). The assignment or activity and final course grades were reported with the research identifier numbers to maintain confidentiality.

The surveys for faculty and students were deployed electronically via e-mail. The faculty survey was deployed via e-mail from the distance learning office. The learner's 
survey was deployed by the faculty member of each course via the learning management e-mail system. Instructors were directed to send three follow-up emails to student participants that had not completed the instruments during the course of each summer or fall session. These communications contained the same notifications as the original communication. 


\section{CHAPTER 4}

\section{RESULTS}

\section{Instructor Surveys}

The instructors rated the intent in the design for the level of student social presence, instructor social presence, and interactive qualities of the assignments volunteered. Of the 29 instructors that volunteered assignments the average student social presence (SSP) score was 48.7 out of a possible 65 points. The Instructor social presence (ISP) average score was 43.6 out of a possible 50 points. The average interactive qualities (IQ) score was 17.5 out of a possible 25 points. Generally, there are a variety of instructors in various subject areas, which believe the volunteered assignments will generate quality interaction and social presence. However, only 15 of these 29 faculty had student participation on the survey and submitted achievement data. The anonymity of the survey prevented separation of those 15 instructors to match them to the student data for further analysis.

Table 3

Instructor Survey Descriptive Statistics

Std.

\begin{tabular}{lcrrrr} 
& $N$ & Minimum & Maximum & Mean & Deviation \\
\hline LSP & 29 & 36 & 65 & 48.7 & 5.4 \\
ISP & 29 & 33 & 50 & 43.6 & 5.0 \\
IQ & 29 & 11 & 24 & 17.5 & 3.5 \\
\hline
\end{tabular}

\section{Student Surveys}

Factor Analysis. Initially, the factorability of all items included on the social presence scale, the interactive quality (IQ) rubric, and the learning satisfaction (LS) scale were examined with an exploratory factor analysis. The varimax rotated component 
matrix revealed that the five items on the interactive qualities matrix and the eight items on the learning satisfaction scale loaded on their respective factors indicating they are relatively homogeneous and unidimensional. However, the social presence scale for student social presence and instructor social presence did not load on their factors, which implies they are multidimensional. The reversed coded items in each of the social presence surveys measuring learner social presence (LSP) and instructor social presence (ISP) were eliminated. Those items were LSP1, LSP 8, LSP9, and SSP10, ISP3, ISP 5, ISP6, and ISP9. Three additional items, LSP7, LSP12, and LSP13 were eliminated from the student social presence scale because one was an item inquiring about the instructor's social presence and the other two because there were very similar items in the learning satisfaction scale. Once these items were eliminated, the factor analysis revealed that each construct was loading in their respective factors. The final varimax rotated component matrix demonstrating that each scale with the included items was loading on their respective factors is presented in Table 4 .

Table 4

Factor Analysis Results

\begin{tabular}{lcccc}
\hline \multicolumn{4}{c}{ Component } \\
& ISP & LS & LSP & IQ \\
\hline LSP2 & & .492 & \\
LSP3 & & & .805 & \\
LSP4 & & & .800 & \\
LSP5 & & & .600 & \\
LSP6 & & & .774 & \\
LSP11 & & & .702 & \\
ISP1 & .854 & & & \\
ISP2 & .860 & & & \\
ISP4 & .762 & & & \\
ISP7 & .710 & & & \\
ISP8 & .718 & & & \\
ISP10 & .734 & & & .785 \\
IQ1 & & & &
\end{tabular}




\begin{tabular}{lll} 
IQ2 & & .815 \\
IQ3 & & .806 \\
IQ4 & & .795 \\
IQ5 & & .765 \\
LS1 & .581 & \\
LS2 & .756 & \\
LS3 & .695 & \\
LS4 & .744 & \\
LS5 & .690 & \\
LS6 & .743 & \\
LS7 & .527 & \\
LS8 & .575 \\
\hline Extraction Method: Principal Component Analysis. \\
Rotation Method Varimax with Kaiser Normalization. \\
a. Rotation converged in 6 iterations.
\end{tabular}

Reliability Analysis. Upon completion of the factor analysis and removal of items that did not appropriately load on their respective factors, reliably for each instrument was calculated using Cronbach's Alpha with the removed items. The student social presence scale with the remaining six items had a reliability of .86 . The instructor social presence scale with the remaining six items had a reliability of .93 . The interactive quality rubric including all five items had a reliability of .92. The learning satisfaction scale including all eight items had a reliability of .88 . The estimates of reliability were consistently high.

\section{Research Question 1}

What types of learner-to-learner (designed or contextual) interactions affect achievement, social presence, and satisfaction in fully online asynchronous undergraduate courses?

To answer research question one, the average ratings for each assignment were used to create an interaction category variable with average ratings of zero to two being contextual interactions and average ratings of three to five being designed interactions. 
There were 77 student surveys from contextual interaction assignments and 150 student surveys from designed interaction assignments. This variable became the independent variable in the ANOVA analysis. The ANOVA results show significant differences for All three achievement measures and the learner satisfaction and learner satisfaction (see Table 5).

Table 5

Research Question 1: ANOVA

\begin{tabular}{|c|c|c|c|c|c|c|}
\hline & & $\begin{array}{l}\text { Sum of } \\
\text { Squares }\end{array}$ & $d f$ & $\begin{array}{l}\text { Mean } \\
\text { Square }\end{array}$ & $F$ & Sig. \\
\hline \multirow{4}{*}{$\begin{array}{l}\text { Assignment/Ac } \\
\text { tivity Grade } \\
(\%)\end{array}$} & Between & 2737.249 & 1 & 2737.249 & 11.512 & $.001 * *$ \\
\hline & Groups & & & & & \\
\hline & Within Groups & 53499.897 & 225 & 237.777 & & \\
\hline & Total & 56237.147 & 226 & & & \\
\hline \multirow{4}{*}{$\begin{array}{l}\text { SOLO Rating } \\
(1-5)\end{array}$} & Between & 9.038 & 1 & 9.038 & 9.145 & $.003 * *$ \\
\hline & Groups & & & & & \\
\hline & Within Groups & 222.371 & 225 & .988 & & \\
\hline & Total & 231.410 & 226 & & & \\
\hline Final Course & Between & 378.678 & 1 & 378.678 & 4.787 & $.030 *$ \\
\hline \multirow[t]{3}{*}{ Grade $(\%)$} & Groups & & & & & \\
\hline & Within Groups & 17799.568 & 225 & 79.109 & & \\
\hline & Total & 18178.246 & 226 & & & \\
\hline \multirow[t]{4}{*}{ LSPaverage } & Between & .300 & 1 & .300 & .897 & .345 \\
\hline & Groups & & & & & \\
\hline & Within Groups & 75.239 & 225 & .334 & & \\
\hline & Total & 75.539 & 226 & & & \\
\hline \multirow[t]{4}{*}{ ISPaverage } & Between & 1.631 & 1 & 1.631 & 2.654 & .105 \\
\hline & Groups & & & & & \\
\hline & Within Groups & 138.285 & 225 & .615 & & \\
\hline & Total & 139.917 & 226 & & & \\
\hline \multirow[t]{4}{*}{$\overline{\text { IQaverage }}$} & Between & .657 & 1 & .657 & 1.146 & .286 \\
\hline & Groups & & & & & \\
\hline & Within Groups & 129.054 & 225 & .574 & & \\
\hline & Total & 129.712 & 226 & & & \\
\hline
\end{tabular}




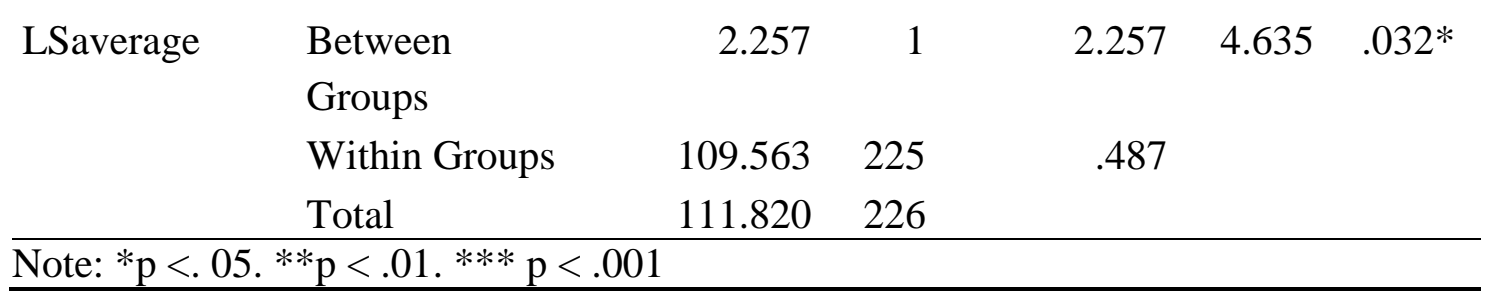

The means and standard deviations of the items with statistically significant differences are presented in Table 6.

\section{Table 6}

Research Question 1: Descriptive statistics of significantly different items

\begin{tabular}{llrrr}
\hline & & \multicolumn{2}{c}{ Std. } \\
& & Mean & Deviation & Std. Error \\
\hline Assignment/Activity Grade & Contextual & 86.31169 & 21.045696 & 2.398380 \\
$(\%)$ & Designed & 93.64633 & 11.538636 & .942126 \\
SOLO Rating (1-5) & Contextual & 3.81 & 1.193 & .136 \\
& Designed & 4.23 & .876 & .072 \\
Final Course Grade (\%) & Contextual & 88.39351 & 10.258557 & 1.169071 \\
& Designed & 91.12159 & 8.110595 & .662227 \\
LS average & Contextual & 3.86688 & .760977 & .086721 \\
& Designed & 4.07750 & .663285 & .054157 \\
\hline
\end{tabular}

The results showed a significant difference in the means of the three achievement measures in favor of the designed interactions. The mean for the contextual assignment was 86 percent while the mean for the designed assignments was 96 percent. This was a full ten points or a letter grade difference depending on grading scale used. The final course grade means showed a similar difference although not as a large a margin. The SOLO rating means were almost a half a point difference, which is a large margin on a five-point scale. This finding provides evidence that designed interactions improve achievement. There was also significant difference in the means in favor of designed interactions effects on learner satisfaction. 
The learning satisfaction scale yielded a significance difference in the overall average of the learning satisfaction items. This result provides evidence that designed interactions produce higher levels of learner satisfaction. There is also some evidence that designed interactions produce increased instructor social presence. Interestingly, five of the six items measuring instructor social presence showed significant differences between designed and contextual interactions, but the instructor social presence average did not show significant differences. There was less evidence that designed interactions affect interaction quality and student social presence.

\section{Research Question 2}

Does the level of instructor social presence affect achievement, quality interaction, and satisfaction in fully online asynchronous undergraduate courses?

To answer research question two the instructor social presence average was divided using a median split technique into a categorical variable of high and low instructor social presence. This variable became the independent variable in the ANOVA analysis with the dependent variables yielding Table 7 . There were 107 student surveys in the low instructor social presence category and 120 student surveys in the high instructor presence category.

\section{Table 7}

Research Question 2: ANOVA

\begin{tabular}{llccccc}
\hline & & Sum of & & Mean & & \\
& & Squares & $d f$ & Square & F & Sig. \\
\hline Assignment/Ac & Between & 1625.735 & 1 & 1625.735 & 6.698 & $.010^{*}$ \\
tivity Grade & Groups & & & & & \\
$(\%)$ & Within Groups & 54611.411 & 225 & 242.717 & & \\
& Total & 56237.147 & 226 & & & \\
\hline
\end{tabular}




\begin{tabular}{|c|c|c|c|c|c|c|}
\hline \multirow{4}{*}{$\begin{array}{l}\text { SOLO Rating } \\
(1-5)\end{array}$} & Between & 9.316 & 1 & 9.316 & \multirow[t]{4}{*}{9.438} & \multirow[t]{4}{*}{$.002 * *$} \\
\hline & Groups & & & & & \\
\hline & Within Groups & 222.093 & 225 & \multirow[t]{2}{*}{.987} & & \\
\hline & Total & 231.410 & 226 & & & \\
\hline \multirow{4}{*}{$\begin{array}{l}\text { Final Course } \\
\text { Grade }(\%)\end{array}$} & Between & 313.153 & 1 & 313.153 & \multirow[t]{4}{*}{3.944} & \multirow[t]{4}{*}{$.048 *$} \\
\hline & Groups & & & & & \\
\hline & Within Groups & 17865.093 & 225 & 79.400 & & \\
\hline & Total & 18178.246 & 226 & & & \\
\hline \multirow[t]{4}{*}{ LSPaverage } & Between & 1.315 & 1 & 1.315 & \multirow[t]{4}{*}{3.987} & \multirow[t]{4}{*}{$.047^{*}$} \\
\hline & Groups & & & & & \\
\hline & Within Groups & 74.224 & 225 & .330 & & \\
\hline & Total & 75.539 & 226 & & & \\
\hline \multirow[t]{4}{*}{ IQaverage } & Between & .795 & 1 & .795 & \multirow[t]{4}{*}{1.388} & \multirow[t]{4}{*}{.240} \\
\hline & Groups & & & & & \\
\hline & Within Groups & 128.917 & 225 & .573 & & \\
\hline & Total & 129.712 & 226 & & & \\
\hline \multirow[t]{4}{*}{ LSaverage } & Between & 2.297 & 1 & 2.297 & \multirow[t]{4}{*}{4.719} & \multirow[t]{4}{*}{$.031 *$} \\
\hline & Groups & & & & & \\
\hline & Within Groups & 109.523 & 225 & .487 & & \\
\hline & Total & 111.820 & 226 & & & \\
\hline
\end{tabular}

The descriptive statistics for the statistically significant items are detailed in Table

8.

\section{Table 8}

Research Question 2: Descriptive statistics of significantly different items

\begin{tabular}{llrrr}
\hline & & \multicolumn{2}{c}{ Std. } \\
& & Mean & Deviation & Std. Error \\
\hline Assignment/Activity Grade & Low ISP & 88.32430 & 18.921731 & 1.829233 \\
$(\%)$ & High ISP & 93.68542 & 11.832170 & 1.080124 \\
SOLO Rating (1-5) & Low ISP & 3.87 & 1.125 & .109 \\
& High ISP & 4.28 & .860 & .078 \\
Final Course Grade $(\%)$ & Low ISP & 88.95236 & 9.372450 & .906069 \\
& High ISP & 91.30529 & 8.478224 & .773952 \\
LSP Average & Low ISP & 4.0156 & .58256 & .05632 \\
& High ISP & 4.1681 & .56694 & .05175 \\
LS average & Low ISP & 3.86688 & .760977 & .086721
\end{tabular}


There are statistically significant differences between the means of the three achievement measures in favor of high instructor social presence. The achievement means for the assignment grade again showed a large margin of more than five points while the overall course means had a margin of more than three points. The SOLO rating showed the highest significant difference with the means almost a half a point different. This indicated that the instructors felt that learners showed learning growth in addition to achieving a high grade. The results provide strong evidence that high instructor presence affects achievement. The three achievement measures yielded significant differences in the means in favor of high instructor social presence.

There is also evidence that the level of instructor social presence affects learner social presence and learning satisfaction. Three items from the learner social presence scale had statistically significant differences between the mean ratings. Two of those items deal with comfort level of the learner and the other is average of the learner satisfaction items. This indicates that a high level of instructor social presence affects learner satisfaction and particularly learner's comfort level for interacting. There is no evidence to support that level of instructor social presence affects interaction quality.

\section{Research Question 3}

Does level of learner social presence affect quality of learner-to-learner interactions, achievement, and satisfaction in fully online asynchronous undergraduate courses? 
To answer research question three a median split technique was used to divide the learner social presence average into a high and low learner social presence categorical variable. This variable became the independent variable in the ANOVA analysis with the dependent variables yielding Table 9. There were 121 student surveys in the low learner social presence category and 106 student surveys in the high learner presence category.

\section{Table 9}

Research Question 3: ANOVA

\begin{tabular}{|c|c|c|c|c|c|c|}
\hline & & $\begin{array}{l}\text { Sum of } \\
\text { Squares }\end{array}$ & $d f$ & $\begin{array}{l}\text { Mean } \\
\text { Square }\end{array}$ & $F$ & Sig. \\
\hline \multirow{4}{*}{$\begin{array}{l}\text { Assignment/Ac } \\
\text { tivity Grade } \\
(\%)\end{array}$} & Between & 656.435 & 1 & 656.435 & 2.657 & .104 \\
\hline & Groups & & & & & \\
\hline & Within Groups & 55580.711 & 225 & 247.025 & & \\
\hline & Total & 56237.147 & 226 & & & \\
\hline \multirow{4}{*}{$\begin{array}{l}\text { SOLO Rating } \\
(1-5)\end{array}$} & Between & 7.900 & 1 & 7.900 & 7.953 & $.005 * *$ \\
\hline & Groups & & & & & \\
\hline & Within Groups & 223.509 & 225 & .993 & & \\
\hline & Total & 231.410 & 226 & & & \\
\hline Final Course & Between & 34.424 & 1 & 34.424 & .427 & .514 \\
\hline \multirow[t]{3}{*}{ Grade (\%) } & Groups & & & & & \\
\hline & Within Groups & 18143.822 & 225 & 80.639 & & \\
\hline & Total & 18178.246 & 226 & & & \\
\hline \multirow[t]{4}{*}{ ISPaverage } & Between & 4.295 & 1 & 4.295 & 7.125 & $.008 * *$ \\
\hline & Groups & & & & & \\
\hline & Within Groups & 135.622 & 225 & .603 & & \\
\hline & Total & 139.917 & 226 & & & \\
\hline \multirow[t]{4}{*}{ IQaverage } & Between & 24.008 & 1 & 24.008 & 51.103 & $.000 * * *$ \\
\hline & Groups & & & & & \\
\hline & Within Groups & 105.704 & 225 & .470 & & \\
\hline & Total & 129.712 & 226 & & & \\
\hline \multirow[t]{4}{*}{ Lsaverage } & Between & 25.199 & 1 & 25.199 & 65.454 & $.000 * * *$ \\
\hline & Groups & & & & & \\
\hline & Within Groups & 86.621 & 225 & .385 & & \\
\hline & Total & 111.820 & 226 & & & \\
\hline
\end{tabular}


The descriptive statistics for the statistically significant items are shown in Table

10.

\section{Table 10}

Research Question 3: Descriptive statistics of significantly different items

\begin{tabular}{llrrr}
\hline & & \multicolumn{3}{c}{ Std. } \\
SOLO Rating (1-5) & Lean & Deviation & Std. Error \\
\cline { 2 - 4 } ISPaverage & High LSP & 4.91 & 1.088 & .099 \\
& Low LSP & 4.037 & .881 & .086 \\
IQaverage & High LSP & 4.313 & .8335 & .0758 \\
& Low LSP & 3.433 & .6055 & .0685 \\
LSaverage & High LSP & 4.085 & .7271 & .0588 \\
& Low LSP & 3.69421 & .613212 & .055747 \\
& High LSP & 4.36203 & .628663 & .061061 \\
\hline
\end{tabular}

There was strong evidence that a high level of learner social presence positively affects level of interaction quality, instructor social presence, and learning satisfaction. The highest margins between the means we over a half a point on the interaction quality scale and the learner satisfaction scale. The margin was slightly less than half a point for the instructor social presence scale. All items in the interactive qualities rubric and the learner satisfaction scale and the overall averages of each showed statically significant differences. There was no evidence to support the effect of level of learner social presence on achievement since there were no significant difference in the assignment/activity and the course grades. However, the instructors rating of student learning on the SOLO taxonomy does show a statistically significant difference. The margin for this difference was more than half a point. This indicates that learner growth along the taxonomy scale is larger when there was a high level of learner social presence. 


\section{Research Question 4}

Does quality of interaction affect level of social presence, achievement, and satisfaction?

To answer research question four a medial split technique was applied to divide the interaction quality average into two categorical variables of high interaction quality and low interaction quality. This variable became the independent variable in the ANOVA analysis with the dependent variables yielding Table 11. There were 122 student surveys in the low interactive qualities category and 105 student surveys in the high interactive qualities category.

\section{Table 11}

Research Question 4: ANOVA

\begin{tabular}{|c|c|c|c|c|c|c|}
\hline & & $\begin{array}{l}\text { Sum of } \\
\text { Squares }\end{array}$ & $d f$ & $\begin{array}{l}\text { Mean } \\
\text { Square }\end{array}$ & $F$ & Sig. \\
\hline \multirow{4}{*}{$\begin{array}{l}\text { Assignment/Ac } \\
\text { tivity Grade } \\
(\%)\end{array}$} & Between & 918.125 & 1 & 918.125 & 3.734 & .055 \\
\hline & Groups & & & & & \\
\hline & Within Groups & 55319.021 & 225 & 245.862 & & \\
\hline & Total & 56237.147 & 226 & & & \\
\hline \multirow{4}{*}{$\begin{array}{l}\text { SOLO Rating } \\
(1-5)\end{array}$} & Between & 11.263 & 1 & 11.263 & 11.512 & $.001 * *$ \\
\hline & Groups & & & & & \\
\hline & Within Groups & 220.146 & 225 & .978 & & \\
\hline & Total & 231.410 & 226 & & & \\
\hline Final Course & Between & 291.190 & 1 & 291.190 & 3.663 & .057 \\
\hline \multirow[t]{3}{*}{ Grade $(\%)$} & Groups & & & & & \\
\hline & Within Groups & 17887.056 & 225 & 79.498 & & \\
\hline & Total & 18178.246 & 226 & & & \\
\hline \multirow[t]{4}{*}{ LSP average } & Between & 21.792 & 1 & 21.792 & 91.225 & $.000 * * *$ \\
\hline & Groups & & & & & \\
\hline & Within Groups & 53.747 & 225 & .239 & & \\
\hline & Total & 75.539 & 226 & & & \\
\hline \multirow[t]{3}{*}{ ISP average } & Between & 2.729 & 1 & 2.729 & 4.476 & $.035^{*}$ \\
\hline & Groups & & & & & \\
\hline & Within Groups & 137.187 & 225 & .610 & & \\
\hline
\end{tabular}




\begin{tabular}{|c|c|c|c|c|c|c|}
\hline & Total & 139.917 & 226 & & & \\
\hline \multirow[t]{4}{*}{ LS average } & Between & 31.803 & 1 & 31.803 & \multirow{4}{*}{\multicolumn{2}{|c|}{$89.428 .000 * * *$}} \\
\hline & Groups & & & & & \\
\hline & Within Groups & 80.017 & 225 & \multirow[t]{2}{*}{.356} & & \\
\hline & Total & 111.820 & 226 & & & \\
\hline
\end{tabular}

The descriptive statistics for the statistically significant items are provided in

Table 12.

Table 12

Research Question 4: Descriptive statistics of significantly different items

\begin{tabular}{llrrr}
\hline & & \multicolumn{3}{c}{ Std. } \\
& & Mean & \multicolumn{1}{c}{ Deviation } & Std. Error \\
\hline SOLO Rating (1-5) & Low IQ & 3.88 & 1.041 & .094 \\
& High IQ & 4.32 & .925 & .090 \\
LSPaverage & Low IQ & 3.8087 & .54574 & .04941 \\
& High IQ & 4.4302 & .41266 & .04027 \\
ISPaverage & Low IQ & 4.064 & .8272 & .0749 \\
& High IQ & 4.284 & .7231 & .0706 \\
LSaverage & Low IQ & 3.65881 & .611536 & .055366 \\
& High IQ & 4.40952 & .578172 & .056424 \\
\hline
\end{tabular}

There was very strong evidence to support that level of interaction quality positively affects the level of social presence for learners and instructors and learner satisfaction. The margin between the means of the learning satisfaction score were the highest at nearly a point. Learner social presence was the next highest margin with over a half a point difference in the means. The instructor social presence was the smallest margin between the means at nearly a quarter of a point. All items in the learner and instructor social presence scale and the learner satisfaction scale in addition to the overall averages of each showed statically significant differences. There was less evidence that level of interaction quality affects achievement. However, the instructors rating of student 
learning on the SOLO taxonomy does show a statistically significant difference in favor of a high level of interactive quality. This indicates that instructors perceived that learner growth along the taxonomy scale was larger when there was a high level of interactive quality. 


\section{CHAPTER 5 \\ DISCUSSION}

\section{Research Question 1}

The results of this research study provide evidence that supports integrating designed interactions into asynchronous online undergraduate courses in order to increase achievement and learner satisfaction. Designed interactions are those that have a high collaborative or cooperative intent. Research has shown that collaborative and cooperative learning are successful techniques to improve achievement in the face-to-face classroom. This study provides evidence that collaborative and cooperative techniques are also successful in the online asynchronous classroom. This finding aligns with metaanalysis results from Borokhovski et.al. (2012) suggesting that the most effective learnerto-learner interaction techniques in distance education or online learning were those designed with the opportunities to work cooperatively.

The terms collaborative and cooperative learning are often used interchangeably. Panitz (1996) separates the two terms defining collaboration as a philosophy of interaction and personal lifestyle whereas cooperation is structure of interaction designed to accomplish a goal. Based upon this defined separation of the terms cooperative learning was used for this discussion.

Cooperative learning has five elements: (1) positive interdependence, (2) promotive interaction, (3) individual and group accountability, (4) social skills, and (5) group processing (Johnson \& Johnson, 2009). Positive interdependence means the group perceives that they need each other to be successful at the given task. Establishing clear goals, joint rewards, shared resources, and assigned roles promotes positive 
interdependence. Promotive interaction refers to learners promoting each other's success by encouraging one another's efforts both academically and personally. Individual and group accountability refers to assessing each members' contributions individually and as a group then providing the results of that assessment to the individual and the group. Social skills refers to basic team work skills such as effective leadership, decisionmaking, trust building, communication, and conflict management. Finally, group processing refers to the group members comfort level of communication to express concerns and celebrate accomplishments.

These elements are similar to the recommendations found through Borokhovski et. al.'s (2012) meta-analysis. They recommended that designers consider four elements when designing interaction to produce higher quality interactions: (a) positive interdependence; (b) individual accountability; (c) promotive interactions, and (d) elaborate explanations. Several assignments from the designed interaction category from this research study illustrated these elements. The results of this study did not show that these elements created higher quality interactions, but they did provide evidence of increased achievement and learner satisfaction. Two examples of designed interactions are described in the following paragraphs.

The first example was a clinical disease assignment for a Biology course on infectious diseases delivered to nursing students. The instructor designed an assignment in which each learner chooses an infectious disease. Upon successful completion of the research paper, each learner took the role of a patient with the infectious disease researched and wrote a symptomatic profile to share with other learners. The other learners then attempted to diagnose the patients. All of this interaction took place on 
threaded discussion boards separated into systems of the body. The instructor provided very clear instructions and grading policies for each element of this assignment. This assignment has the following elements: positive interdependence, promotive interaction, individual accountability, and group processing.

The second example was the gerontological conference group project in a gerontology-nursing course. This group project contained several learning activities completed throughout the duration of the course. The instructor placed the students in random groups and they were asked to identify a topic for this project, which required instructor approval. Once the topic was approved, each group member completed an article critique on a peer reviewed journal article for the selected topic. The critiques were submitted and graded individually by the instructor. Next, the group developed a narrated presentation describing all of the articles and synthesizing the findings. All presentations were posted on a discussion board for peer review by the other learners. This instructor also provided very clear instructions and grading rubrics for each learning activity. This assignment contains the following elements: promotive interaction, individual accountability, and group processing.

Both examples exhibit individual accountability and group processing. They incorporate individual accountability by requiring an individual component to the assignment in the form of a research paper and learners were held individually accountable for their participation in the discussion and presentation. They incorporate group processing by allowing the learners to process new information in a group setting. These two elements were common denominators for all the assignments and activities in the designed interaction categories. This finding provides support for incorporating 
elements of cooperative learning when designing online interactive activities to increase the probability higher levels of achievement and learning satisfaction. This result was not consistent with results found by Oyarzun and Morrison (2013). They discovered that online cooperative learning did not have significant effects on achievement, but did have significant effects learner satisfaction.

These examples provide practical strategies on how to incorporate cooperative learning elements into online assessments/activities. They also show that designed interactions are broader than learner-to-learner interaction. They include all types of interaction to create a learning experience. Wang, Chen, and Anderson (2014) have developed a framework for online interaction and cognitive engagement. They used theory building methodology to create the following framework for four levels of interaction: operation interaction, wayfinding interaction, sense-making interaction, and innovative interaction. Innovative interaction has the highest level of cognitive engagement and requires the production and sharing of learning artifacts. Through these experiences, learners also have the other three levels of interactions: operation, wayfinding, and sense-making. The examples of designed interaction provided include producing and sharing of learning artifacts and this was aligned with the groupprocessing element of cooperative learning. The results of this research study support this idea as well with the designed interactions assignment/activities having the qualities of innovative interactions.

\section{Research Question 2}

The results of this research study also highlight the importance of instructor social presence on student achievement, learning satisfaction and learner social presence 
particularly the comfort level of learners interacting. This finding was in agreement with the research of So and Brush (2008) although their research study was conducted in a blended learning environment. Interestingly, the instructor with the highest social presence rating was also the instructor that had the assignment with the highest rating for cooperative learning intent. The Biology instructor with the clinical disease assignment outlined previously had the highest rating. Unfortunately, instructor techniques used for increasing instructor social presence was not collected in the survey data of this study. This topic could be a fruitful area for future research. However, Plante and Asselin (2014) conducted a literature review to identify best practices for creating social presence. They identified those faculty interactions that were respectful, positive, encouraging, and frequent fostered social presence. Similarly, Aragon (2003) offers these practical suggestions for increasing instructor social presence: instructors participate in interactions, answer inquiries promptly, provide frequent feedback, share personal stories and experiences, use humor, address students by name, and allow learners options for addressing instructor.

\section{Research Question 3}

The effects of level of learner social presence on level of interaction quality and learner satisfaction were very strong in the results of this research study. These results encourage planning interactive activities with level of learner social presence in mind to increase interaction quality and learner satisfaction. Level of social presence effects on learning satisfaction was a conclusion well represented in research (Gunawardena \& Zittle, 1997; Hostetter \& Busch, 2006; Richarson \& Swan, 2003). The level of social presence effects on interaction quality was a conclusion less represented in research. 
Sebastianelli, Swift and Tamimi (2015) examined factors of perceived learning, satisfaction, and quality. They found that course content was the strongest predictor for all three outcomes. They additionally found that instructor to learner interaction had a positive impact on satisfaction but not quality. However, quality influences learner-tolearner interaction. This last conclusion was consistent with the results of this study.

\section{Research Question 4}

This study also showed that a high level of interactive quality significantly affected levels of both learner and instructor social presence and learner satisfaction. This result was partially consistent with Alderman's (2005) study that analyzed a highly cooperative course design with the interactive quality rubric developed by Roblyer and Wiencke (2003) used in the current study. They concluded that quality interaction was an essential contributor to perceive achievement and learner satisfaction. However, social presence was not measured.

There was not an identifiable course or instructor with the highest interactive quality rating. Twenty-three students reported the highest rating possible of 25 points and of those, the highest frequency of an instructor was five. This result implies that no single instructor designed activities with all five of the interactive qualities in mind. The interactive quality rubric contained five separate elements: (1) social/rapport designs for interaction, (2) instructional designs for interaction, (3) interactivity of technology resources, (4) evidence of learner engagement, and (5) evidence of instructor engagement. All elements increased significantly when learner social presence was high.

The rubric descriptions provide insights to increasing each element. Strong social rapport building includes providing for exchanges of personal information and 
encouraging student-student and instructor-student interaction in addition to providing ongoing course structures designed to promote social rapport among students and instructor. Strong instructional designs require learners to communicate with the instructor in addition to instructional activities requiring learners to develop products by working together cooperatively (e.g., in pairs or small groups) and share results and feedback with other groups in the class. Strong interactive technologies allow two-way exchanges of text, audio, and/or video between instructors and learners. Evidence of learner engagement was high when nearly all learners are replying and initiating messages when required and voluntary. These messages are detailed, responsive to topics, and are well developed. Evidence of instructor engagement was prompt responses to inquiries, detailed and prompt feedback, along with hints and information to supplement learning.

There are some common themes in previous results and these descriptions. Social report building and instructor engagement are similar to instructor social presence. Strong instructional design equates to designed interactions and more specifically to the groupprocessing element of cooperative learning. Evidence of learner engagement equates to the comfort level items of student social presence. This result provides support that the combination of designed interactions coupled with high instructor and learner social presence improves interaction quality.

Additionally, Puzziferro and Shelton (2008) offered a similar model for developing high quality online courses that include three elements that converge to create what they call an active mastery learning experience. The three elements are content mastery in which learners engage in engaging activities to master content, interactions in 
which learners engage with each other and the instructor through learning activities, discussions, and projects, and active application in which learners apply content through collaborative, problem-based activities that are relevant and meaningful.

\section{Implications for Practice}

The results of this study indicate that incorporating designed interactions increase learner achievement and satisfaction. Designed interactions can have a cooperative learning intent. Instructors should create designed interactions that align to course learning outcomes. These interactions should include (a) positive interdependence; (b) individual accountability; (c) promotive interactions, and (d) elaborate explanations. The assignments/activities identified as the most cooperative in this research study also spanned multiple modules or chucks of instruction and had multiple products or checkpoints. This design element allowed for more learner -to-instructor and learner-tocontent interaction in addition to the learner-to-learner interactions.

It was advised that instructors contemplate a designed interaction/activity in the initial phase of designing an online course. This interaction/activity should allow learners to individually and cooperatively apply the new concepts. For example, an introduction level Spanish course may have a learning outcome of describing family relationships in Spanish. This outcome could inform a learning activity in which each student creates a graphic representation of their family tree (individual accountability), share and describe that family tree in an asynchronous or synchronous video conversation with a single classmate (elaborate explanations). Students could be instructed to gather more in depth information regarding at least one of their partner's family members and something they both have in common through the conversation. They could then submit 
a short story about the information they gathered (positive interdependence and promotive interactions). This has three checkpoints and each activity or interaction should have specific instructions and rubrics for assessment.

\section{Implications for Research}

This non-experimental research study provides support that designed interactions or cooperative learning activities increase achievement and learner satisfaction. A fruitful direction for research in the area of learner-to-learner interactions in asynchronous online learning would be experimental research studies test specific methodologies such as cooperative learning that are successful in various levels and subject areas.

This study did not measure levels of motivation. However, reflecting upon the high rated assignment instructions it appears that motivation would also increase. This measure might be a fruitful addition in future research as well.

\section{Limitations}

This research study was limited to courses volunteered by the faculty members and relied on those faculty members to report the achievement data and distribute surveys resulting in a lower participation rate. Some faculty members only distributed the surveys or only reported the achievement data. Incentives provided for participation differed amongst faculty participants. Some faculty rewarded students for participation while others chose not to reward for participation on the surveys. This led to various levels of student survey participation within the courses. One course had only one survey respondent, which warranted elimination from the data set. Others had the entire class participate. 
This research study examined previously designed assignments. Therefore, the number of surveys in each comparison group was unknown until the completion of data collection. The data collect period had to be extended sue to uneven and low amount of surveys in one of the groups.

\section{CONCLUSION}

According to the results of the non-experimental comparative research study, designed interactions that have a cooperative intent increase learners achievement and level of satisfaction. Designed interactions should include (a) positive interdependence; (b) individual accountability; (c) promotive interactions, and (d) elaborate explanations. Multiple products or checkpoints that span several chunks of content may also be useful strategies to create all three types of interaction.

The effect social presence had on achievement, satisfaction, and interaction quality were mixed. A higher level of instructor social presence increases learner's achievement, level of learner social presence, and level of learner satisfaction. Having multiple products can assist in creating higher instructor social presence because it provides multiple opportunities for the instructor and student to interact. A higher level of learner social presence increases level of interactive quality and level of learner satisfaction. Providing opportunities for the students to interact whether they are designed or contextual can enhance learner social presence.

The findings suggest that higher levels of interaction quality increased levels of instructor social presence, learner social presence, and learner satisfaction. The quality of interaction may be a stronger predictor for level of social presence and learner satisfaction. More research in this area is needed to validate this conclusion. Further 
research is also recommended to identify and validate the relationships between these variables and best practices in designing interactive experiences in online asynchronous undergraduate courses. 


\section{References}

Alderman, B. (2005). The Role of Interaction in Enhancing Achievement and Student Satisfaction in an Online Course: A Rubric Analysis. In G. Richards (Ed.), Proceedings of E-Learn: World Conference on E-Learning in Corporate, Government, Healthcare, and Higher Education 2005 (pp. 214-219). Chesapeake, VA: Association for the Advancement of Computing in Education (AACE).

Allen, I.E. \& Seaman, J. (2013). Grade Change: Tracking Online Education in the United States 2013, Babson Survey Research Group. Retrieved 3/10/14 from, http://sloanconsortium.org/publications/survey/grade-change-2013

Aragon, S. R. (2003). Creating Social Presence in Online Environments. New Directions for Adult \& Continuing Education, (100), 57-68. doi:10.1002/ace.119

Argyle, M. \& Dean, J. (1965). Eye contact, distance and affiliation. Sociometry, 28(3), 289-304.

Bernard, R. M., Abrami, P. C., Borokhovski, E., Wade, C. A., Tamim, R. M., Surkes, M. A., \& Bethel, E. C. (2009). A meta-analysis of three types of interaction treatments in distance education. Review of Educational Research, 79, 12431289. Doi 10.3102/0034654309333844

Bol, L., \& Garner, J. K. (2011). Challenges in supporting self-regulation in distance education environments. Journal of Computing in Higher Education, 23(2-3), 104-123.

Bonnell, K. H., Katz, B. A., \& Evey, J. A. (2009). Asynchronous communication in distance learning programs. Kentucky Journal Of Communication, 28(1), 1-17. 
Borokhovski, E., Tamim, R., Bernard, R. M., Abrami, P. C., \& Sokolovskaya, A. (2012). Are Contextual and Designed Student-Student Interaction Treatments Equally Effective in Distance Education? Distance Education, 33(3), 311-329.

Brewer, S. A., \& Klein, J. D. (2004). Small group learning in an online asynchronous environment. Paper presented at the annual meeting of the Association for Educational Communications and Technology, Chicago, IL.

Biggs, J. B., \& Collis, K. F. (1982). Evaluating the quality of learning: The SOLO taxonomy (Structure of the Observed Learning Outcome). Academic Press.

Caspi, A., \& Blau, I. (2008). Social presence in online discussion groups: Testing three conceptions and their relations to perceived learning. Social Psychology of Education, 11(3), 323-346.

Davidson-Shivers, G. (2009). Frequency and types of instructor interactions in online instruction. Journal of Interactive Online Learning, 8(1), 23-40.

Fulford, C. \& Zhang S. (1993). Perceptions of interaction: The critical predictor in distance education. The American Journal of Distance Education, 7(3), 8-2 1.

Garrison, D. R., Anderson, T., \& Archer, W. (2000). Critical inquiry in a text-based environment: Computer conferencing in higher education. The Internet and Higher Education, 2(2-3), 87-105.

Grandzol, C. J., \& Grandzol, J. R. (2010). Interaction in online courses: More is not always better. Online Journal of Distance Learning Administration, 13, 1-18.

Gunawardena, C. N. (1995). Social presence theory and implications for interaction collaborative learning in computer conferences. International journal of education telecommunications, 1(2/3): 147-166. 
Gunawardena, C. N., \& Zittle, F. (1995). An examination of teaching and learning processes in distance education and implications for designing instruction. In: M.F. Beaudoin (Ed.), Distance education symposium 3: Instruction (pp.51-63). ACSDE Research Monograph, Vol. 12, University Park, PA: The Pennsylvania State University.

Gunawardena, C., \& Zittle, F. (1997). Social presence as a predictor of satisfaction within a computer mediated conferencing environment. American Journal of Distance Education, 11(3), 8-26

Hillman, D. C., Willis, D. J. \& Gunawardena, C. N. (1994). Learner-interface interaction in distance education: an extension of contemporary models and strategies for practitioners. The American Journal of Distance Education, 8(2), 30-42.

Horzum, M. B. (2015). Interaction, Structure, Social Presence, and Satisfaction in Online Learning. Eurasia Journal Of Mathematics, Science \& Technology Education, 11(3), 505-512. doi:10.12973/eurasia.2014.1324aHyo-Jeong S. (2010). Towards rigor of online interaction research: Implication for future distance learning research. The Turkish Journal of Education Technology. 9(2).

Hostetter, C., \& Busch, M. (2006). Measuring up online: The relationship between social presence and student learning satisfaction. Journal of Scholarship of Teaching and Learning, 6(2), 1-12.

Hyo-Jeong, S. O. (2010). Towards rigor of online interaction research: Implication for future distance learning research. TOJET: The Turkish Online Journal of Educational Technology, 9(2). 
Johnson, G. (2006). Synchronous and asynchronous text-based CMC in educational contexts: A review of recent research. TechTrends: Linking Research \& Practice to Improve Learning, 50(4), 46-53. doi: 10.1007/s11528-006-0046-9

Johnson, D. W., \& Johnson, R. T. (2009). An Educational Psychology Success Story: Social Interdependence Theory and Cooperative Learning. Educational Researcher, 38(5), 365-379. http://dx.doi.org/10.3102/0013189X09339057

Jung, I., Choi, S., Lim, C., \& Leem, J. (2002). Effects of different types of interaction on learning achievement, satisfaction and participation in web-based instruction. Innovations in Education and Teaching International, 39(2), 153-162.

Kiriakidis, P. \& Parker, A. (2008). Faculty and learner interaction in online courses. International Journal of Instructional Technology and Distance Learning, 5(11).

Kožuh, I., Jeremić, Z., Sarjaš, A., Bele, J. L., Devedžić, V., \& Debevc, M. (2015). Social presence and interaction in learning environments: the effect on student success. J. Educ. Technol. Soc, 18(1), 223-236.

Kuo, Y.C., Walker, A., Belland, B. R., \& Schroder, K. E. E. (2013). A predictive study of student satisfaction in online education programs. International Review of Research in Open and Distance Learning, 14(1), 16-39.

Kuo, Y. C., Walker, A., Schroder, K. E. E., \& Belland, B. R. (2014). Interaction, Internet self-efficacy, and self-regulated learning as predictors of student satisfaction in online education courses. The Internet and Higher Education, 20, 35-50. doi:10.1016/j.iheduc.2013.10.001 
Lowenthal, P. R. (2010). The evolution and influence of social presence theory on online learning. To appear in T. T. Kidd (Ed.), Online education and adult learning: New frontiers for teaching practices. Hershey, PA: IGI Global.

Lou, Y., Abrami, P. C., \& d'Apollonia, S. (2001). Small group and individual learning with technology: A meta-analysis. Review of Educational Research, 71, 449-521. doi:10.3102/00346543071003449

Mehrabian, A. (1969). Some referents and measures of nonverbal behavior. Behavior Research Methods and Instrumentation, 1(6), 205-207.

Moore, M. G. (1989). Editorial: Three types of interaction. The American Journal of Distance Education, 3(2), 1-6.

Mykota, D., \& Duncan, R. (2007). Learner characteristics as predictors of online social presence. Canadian Journal of Education, 30(1), 157-170.

Oncu, S., \& Ozdilek, Z. (2013). Learning with peers: an interdisciplinary comparative study of learner interaction and satisfaction on an instructional design course. Educational Sciences: Theory and Practice, 13(2), 1251-1261.

Oyarzun, B. A., \& Morrison, G. R. (2013). Cooperative learning effects on achievement and community of inquiry in online education. Quarterly Review of Distance Education, 14(4), 181-194, 255.

Panitz, T. (1996) Collaborative versus Cooperative Learning - A Comparison of The Two Concepts which Will Help Us Understand the Underlying Nature of Interactive Learning. Cape Cod Community College, peninsula, Massachusetts, USA. Retrieved Feb. 2016, from http://home.capecod.net/ tpanitz/tedsarticles/coopdefinition.htm. 
Palloff, R. \& Pratt, K. (2001). Lessons from cyberspace to the classroom: The realities of online teaching. San Francisco: Jossey-Bass.

Plante, K. \& Asselin, M.E. (2014). Best Practices for Creating Social Presence and Caring Behaviors Online. Nursing Education Perspectives, 35(4), 219-223 5p. doi:10.5480/13-1094.1

Picciano, A. G. (1998). Developing an asynchronous course model at a large, urban university. Journal of Asynchronous Learning Networks, 2 (1), 1-14.

Picciano, A. G. (2002). Beyond student perceptions: Issues of interaction, presence, and performance in an online course. Journal of Asynchronous Learning Networks, $6(1), 21-40$.

Pollard, H., Minor, M., \& Swanson, A. (2014). Instructor social presence within the community of inquiry framework and its impact on classroom community and the learning environment. Online Journal of Distance Learning Administration, 17(2).

Puzziferro, M. \& Shelton, K. (2008). A model for developing high-quality online courses: Integrating a systems approach with learning theory. Journal of Asynchronous Learning Networks, 12(3). 119-136.

Rafaeli, S. (1988). Interactivity: From new media to communication. In Advancing Communication Science: Merging Mass and Interpersonal Process, ed R. P Hawkins, J. M. Weinmann, \& S. Pengree, 110-134, Newberry Park, CA: Sage Richardson, J. C., \& Swan, K. (2003). Examining social presence in online courses in relation to students' perceived learning and satisfaction. Journal of Asynchronous Learning Networks, 7(1), 68-88. 
Roblyer, M. D. \& Wiencke, W. R. (2003) Design and use of a rubric to assess and encourage interactive in distance courses. The American Journal of Distance Education, 17(2), 77-98.

Rourke, L., \& Kanuka, H. (2009). Learning in communities of inquiry: A review of the literature. Journal of Distance Education, 23(1), 19-48.

Rovai, A. P. (2001). Building classroom community at a distance: A Case Study. Educational Technology Research and Development, 49(4).

Rovai, A. (2002). Building Sense of Community at a Distance. The International Review of Research in Open and Distributed Learning, 3(1). Retrieved from http://www.irrodl.org/index.php/irrodl/article/view/79/152

Sebastianelli, R., Swift, C., \& Tamimi, N. (2015). Factors Affecting Perceived Learning, Satisfaction, and Quality in the Online MBA: A Structural Equation Modeling Approach. Journal of Education for Business, 90(6), 296-305.

Shackelford, J. L., \& Maxwell, M. (2012). Sense of Community in Graduate Online Education: Contribution of Learner to Learner Interaction. International Review of Research in Open \& Distance Learning, 13(4), 228-249.

Sher, A. (2009). Assessing the relationship of student-instructor and student-student interaction to student learning and satisfaction in web-based online learning environment. Journal of Interactive Online Learning, 8(2), 102-120.

Short, J. A., Williams, E., \& Christie, B. (1976). The social psychology of telecommunications. London: Wiley. 
So, H. J., \& Brush, T. A. (2008). Student perceptions of collaborative learning, social presence and satisfaction in a blended learning environment: Relationships and critical factors. Computers \& Education, 51(1), 318-336.

Stein, D. S., Wanstreet, C. E., Calvin, J., Overtoom, C., \& Wheaton, J. E. (2005). Bridging the transactional distance gap in online learning environments. American Journal of Distance Education, 19(2), 105-118.

Swan, K. (2003). Learning effectiveness: what the research tells us. In J. Bourne \& J. C. Moore (Eds) Elements of Quality Online Education, Practice and Direction. Needham, MA: Sloan Center for Online Education, 13-45.

Swan, K., \& Shih, L. F. (2005). On the nature and development of social presence in online course discussions. Journal of Asynchronous learning networks, 9(3), 115 136.

Taylor, D. L. (2014). Interactions in online courses and student academic success (Order No. 3671767). Available from ProQuest Dissertations \& Theses Global. (1651237829). Retrieved from http://search.proquest.com/docview/1651237829?accountid=12967

Thurmand, V. A., Wambach, K., Connors, H. R., \& Frey, B. B. (2002). Evaluation of Student Satisfaction: Determining the impact of a web-based environment by controlling for student characteristics. The American Journal of Distance Education, 16, 169-89.

Tu, C. H. (2000). On-line learning migration: From social learning theory to social presence theory in a CMC environment. Journal of Network and Computer Applications, 23(1), 27-37. 
$\mathrm{Tu}, \mathrm{C}$. (2002). The measurement of social presence in an online learning environment. International Journal on E-Learning, 1(2), 34-45.

Tu, C. H., \& McIsaac, M. S. (2002). The relationship of social presence and interaction in online classes. The American Journal of Distance Education, 16(3), 131-150.

Wagner, E. D. (1994). In support of a functional definition of interaction. American Journal of Distance Education. 8(2), 6-29.

Wang, Z., Chen, L., \& Anderson, T. (2014). A framework for interaction and cognitive engagement in connectivist learning contexts. The International Review of Research in Open And Distributed Learning, 15(2). Retrieved from http://www.irrodl.org/index.php/irrodl/article/view/1709/2838.

Wei, H., Peng, H., \& Chou, C. (2015). Can more interactivity improve learning achievement in an online course? Effects of college students' perception and actual use of a course-management system on their learning achievement. Computers \& Education, 8310-21. doi:10.1016/j.compedu.2014.12.013

Weinel, M., Bannert, M., Zumbach, J., Hoppe, H. U., \& Malzahn, N. (2011). A closer look on social presence as a causing factor in computer-mediated collaboration. Computers in Human Behavior, 27(1), 513-521.

Whipp, J. L., \& Lorentz, R. A. (2009). Cognitive and social help giving in online teaching: an exploratory study. Educational Technology Research and Development, 57(2), 169-192. 


\section{APPENDICES}

\section{Appendix A - Solicitation e-mail}

Dear Online Instructor,

You are receiving this email because you are scheduled to teach an online asynchronous course in the summer I or summer II 2015 semesters. Beth Oyarzun from the Office of e-Learning is collecting data regarding learner-to-learner interactions effects on achievement, social presence, and learner satisfaction in asynchronous online courses for her dissertation study through Old Dominion University.

This is an important topic in on-line learning because the learner-to-learner interactions have been linked to course satisfaction and performance. Your assistance would be greatly appreciated, and the information could potentially advance our understanding of how to promote more effective interactions among students. You will receive a brief paper regarding best practice findings from the results of the study.

Beth is seeking approximately 20 online asynchronous instructors to volunteer a course and a single assignment/activity within that course that is graded and requires students to interact with one another for analysis. Instructors and students within these courses will be asked to complete a few data collection instruments via electronic survey that will take approximately 10 minutes. Instructors will additionally be asked to provide the grades on the assignment/activity, final course grades, and a rating of each participant's level of learning. Collecting and reporting the achievement data should take approximately 45 minutes. These will be provided to the researcher anonymously using a identifier number generated by the students and e-mailed to instructors.

The College Human Subjects Committee has approved all forms. If you have any questions about this project, you can contact Beth Oyarzun at (910) 962-2417, Dr. Jill Stefaniak at 757-683-6696, Dr. Linda Bol at (757) 683-4584, or Dr. Edward Gomez, the Chair of the Human Subjects Committee in the College of Education at 757-683-6309.

To volunteer (click here)

Thank you,

Office of e-Learning

UNCW 


\section{Appendix B - Volunteer Survey}

1) What is your first name?

2) What is your last name?

3) What is your e-mail address?

4) What course and section number you would like to volunteer? (ex: EDN-301-800)

5) Which Activity/Assignment within that you would like to volunteer? (ex: Lesson plan project)

6) Where are the instructions for this assignment/activity located within the course? (ex: learning modules - module 3 - Lesson Plan project folder)

7) Do you provide permission to the researcher and a co-rater to gain access to the course shell to analyze the volunteered assignment/activity instructions?
a. Yes
b. No 


\section{Appendix C - Instructor Instructions}

Dear Instructor:

You are about to complete an online survey regarding your design experience in a course module that you volunteered for this study. It will only take 10-15 minutes of your time. Whether you participate or not is, of course, up to you but we hope you will. It will not cost you anything but would be greatly appreciated. We are collecting this information to help us evaluate the quality and effectiveness of online interactions, and need to get instructor feedback.

All information we collect will remain confidential. There will be no names used and there will be no possibility anyone could trace a particular response back to a particular person. In any case, you should still remember that if there is any item that you want to leave blank, that is OK.

These forms have been approved by the College Human Subjects Committee. If you have any questions about this project, you can contact Dr. Jill Stefaniak 757-6836696 at or Dr. Linda Bol at (757) 683-4584, Beth Oyarzun (910) 962-2417 or Dr. Edward Gomez, the Chair of the Human Subjects Committee in the College of Education 757683-6309.

Your participation in this evaluation will provide valuable information that can use to improve online instruction. You will be provided a pamphlet of best practices identified from this study.

To begin the survey (Click here.)

Sincerely,

Beth Oyarzun

Instructional Designer

Office of e-Learning

UNCW 


\section{Appendix D - Instructor Identifier Form}

Please record your student names and Identifier numbers in this chart. You will need this information to report assignment/activity grades to the researcher. Please keep this information under password or locked. Do not submit this form to the researcher. Store in a secure location until notified by the researcher to destroy. Student Identifier Number Chart

\begin{tabular}{|l|l|}
\hline Name & Identifier Number \\
\hline & \\
\hline & \\
\hline & \\
\hline & \\
\hline & \\
\hline & \\
\hline & \\
\hline & \\
\hline & \\
\hline & \\
\hline & \\
\hline & \\
\hline & \\
\hline & \\
\hline & \\
\hline & \\
\hline & \\
\hline & \\
\hline & \\
\hline & \\
\hline & \\
\hline & \\
\hline & \\
\hline & \\
\hline & \\
\hline & \\
\hline & \\
\hline & \\
\hline & \\
\hline & \\
\hline & \\
\hline & \\
\hline & \\
\hline
\end{tabular}




\section{Appendix E - Instructor Grade Reporting Form}

Once Assignment/Activity is complete use the following chart to report grades to the researcher. The SOLO rubric is an additional measure of learner achievement. Rate each student's level of understanding of the topic on which your assignment/activity is designed to measure: 1 being the lowest level of understanding and 5 being the highest level of understanding. Please refer to rubric on following page for further explanation.

\begin{tabular}{|c|c|c|c|}
\hline Identifier Number & $\begin{array}{c}\text { Grade on } \\
\text { Assignment/Activity (\%) }\end{array}$ & SOLO Rating (1-5) & $\begin{array}{c}\text { Final Course Grade } \\
(\%)\end{array}$ \\
\hline & & & \\
\hline & & & \\
\hline & & & \\
\hline & & & \\
\hline & & & \\
\hline & & & \\
\hline & & & \\
\hline & & & \\
\hline & & & \\
\hline & & & \\
\hline & & & \\
\hline & & & \\
\hline & & & \\
\hline & & & \\
\hline & & & \\
\hline & & & \\
\hline & & & \\
\hline & & & \\
\hline & & & \\
\hline & & & \\
\hline & & & \\
\hline & & & \\
\hline & & & \\
\hline
\end{tabular}

\section{Appendix F - SOLO Rubric for Instructor Reference}


The SOLO rubric is an additional measure of learner achievement. Rate each student's level of understanding of the topic on which your assignment/activity is designed to measure: 1 being the lowest level of understanding and 5 being the highest level of understanding. Insert each student's SOLO score into the Grade Reporting Form on previous page.

\begin{tabular}{|l|l|c|}
\hline $\begin{array}{c}\text { Student Level of } \\
\text { Thinking and Learning }\end{array}$ & \multicolumn{1}{c|}{ Learning Task } & $\begin{array}{c}\text { Score for Grade } \\
\text { Reporting Form }\end{array}$ \\
\hline Pre-structural & $\bullet \quad$ I am unsure about... & 1 \\
\hline Uni-structural & $\bullet \quad$ I have one relevant idea about... & 2 \\
\hline Multi-structural & $\bullet \quad$ I have several ideas about... & 3 \\
\hline Relational & $\begin{array}{l}\text { - I have several ideas about.... } \\
\text { I can link these ideas to the big } \\
\text { Eicture. }\end{array}$ & 4 \\
\hline Extended abstract & $\begin{array}{l}\text { - I have several ideas about... } \\
\text { I can link them to the big picture. } \\
\text { I can look at these ideas in a new } \\
\text { and different way. }\end{array}$ & 5 \\
\hline
\end{tabular}




\section{Appendix G - Instructor Demographic Survey}

1. What is the subject area of your course?

a. Sciences (Biology and Marine Biology, Chemistry, Physics, Computer Science, Environmental Studies, Geography and geology, Math and Statistics, Physics and Oceanography, Pre-engineering)

b. Health and Human Applied Sciences (Nursing, Social Work, and Exercise Science, public health, tourism, recreation therapy, clinical research, physical education)

c. Education

d. Business

e. Social Sciences (Anthropology, Communications, History, International Studies, Public and International affairs, Psychology, Sociology and Criminology)

f. Cultural arts (Art and Art history, Creative Writing, English, Film studies, Foreign Language and Literature, Music, Philosophy and Religion)

g. Other

2. Select your age range.
a) $20-30$
b) $30-40$
c) $40-50$
d) $50-60$
e) Over 60

2. Select your gender.
a) Male
b) Female

3. What is your classification?
a) Assistant Professor
b) Associate Professor
c) Professor
d) Lecturer
e) Other

4. What is your level of computer skill?

a) Minimal Knowledge (not able to do computer related tasks without assistance)

b) Some Knowledge, Need assistance at times (able to power on/off computer, access internet, check e-mail)

c) Comfortable with Computers (Can do some trouble shooting when issues arise, can learn new applications without assistance)

d) Advanced (able to do advanced troubleshooting, the person friends a family call when they need assistance)

5. Approximately how many online classes have you taught? 

a) $1-2$
b) $3-4$
c) $5-10$
d) More than 10

6. Have you received any training in online teaching methodology?
a) Yes
b) No

7. Have you received any training in instructional design?
a) Yes
b) No

8. Was this course self-designed or designed by someone else?

a) Self-designed

b) Designed by another instructor

c) Designed by an instructional designer or instructional design team 


\section{Appendix H - Instructor Social Presence Scale}

\section{Social Presence Scale}

\begin{tabular}{|c|c|c|c|c|c|}
\hline & $\begin{array}{l}\text { Strongly } \\
\text { Disagree }\end{array}$ & Disagree & Neutral & Agree & $\begin{array}{l}\text { Strongly } \\
\text { Agree }\end{array}$ \\
\hline \multicolumn{6}{|l|}{$\begin{array}{l}\text { Interactions during the } \\
\text { assignment/activity are designed to be } \\
\text { impersonal. }\end{array}$} \\
\hline \multicolumn{6}{|l|}{$\begin{array}{l}\text { Online asynchronous interaction is an } \\
\text { excellent medium for social interaction. }\end{array}$} \\
\hline \multicolumn{6}{|l|}{$\begin{array}{l}\text { I will feel comfortable conversing } \\
\text { through the medium provided. }\end{array}$} \\
\hline \multicolumn{6}{|l|}{$\begin{array}{l}\text { I will feel comfortable introducing } \\
\text { myself during this assignment/activity. }\end{array}$} \\
\hline \multicolumn{6}{|l|}{$\begin{array}{l}\text { If introductions are completed, the } \\
\text { introductions enable me to form a sense } \\
\text { of online community. }\end{array}$} \\
\hline \multicolumn{6}{|l|}{$\begin{array}{l}\text { I will feel comfortable participating } \\
\text { with classmates in this } \\
\text { assignment/activity. }\end{array}$} \\
\hline \multicolumn{6}{|l|}{$\begin{array}{l}\text { I designed the activity/assignment to } \\
\text { create a feeling of an online community. }\end{array}$} \\
\hline \multicolumn{6}{|l|}{$\begin{array}{l}\text { I will facilitate student interactions } \\
\text { during the assignment/activity. }\end{array}$} \\
\hline \multicolumn{6}{|l|}{$\begin{array}{l}\text { Online Interactions tend to be more } \\
\text { impersonal in the online medium than } \\
\text { face-to-face discussions }\end{array}$} \\
\hline \multicolumn{6}{|l|}{$\begin{array}{l}\text { Online Interactions are more impersonal } \\
\text { than audio teleconference discussions. }\end{array}$} \\
\hline \multicolumn{6}{|l|}{$\begin{array}{l}\text { Online interactions are more impersonal } \\
\text { than video teleconference discussions. }\end{array}$} \\
\hline \multicolumn{6}{|l|}{$\begin{array}{l}\text { I will feel comfortable interacting with } \\
\text { other participants in this } \\
\text { assignment/activity. }\end{array}$} \\
\hline \multicolumn{6}{|l|}{$\begin{array}{l}\text { I feel that other participants will } \\
\text { acknowledge my point of view during } \\
\text { this assignment/activity. }\end{array}$} \\
\hline \multicolumn{6}{|l|}{$\begin{array}{l}\text { I feel that I will be able to form distinct } \\
\text { individual impressions of some } \\
\text { participants even though we } \\
\text { communicated only online. }\end{array}$} \\
\hline \multicolumn{6}{|l|}{ I am a caring person with the students. } \\
\hline \multicolumn{6}{|l|}{$\begin{array}{l}\text { I am NOT professional with the } \\
\text { students. }\end{array}$} \\
\hline I am humble with the students. & & & & & \\
\hline
\end{tabular}




\begin{tabular}{|l|l|l|l|l|l|}
\hline $\begin{array}{l}\text { I do NOT provide open } \\
\text { communications. }\end{array}$ & & & & & \\
\hline I do NOT create unity. & & & & & \\
\hline I create an attitude of sharing. & & & & & \\
\hline $\begin{array}{l}\text { I create an attitude of group } \\
\text { encouragement. }\end{array}$ & & & & & \\
\hline I do NOT draw the class together. & & & & & \\
\hline I grade student's performance fairly. & & & & & \\
\hline
\end{tabular}




\section{Appendix I - Instructor Interaction Quality Scale}

\section{Carefully rate the quality of interaction in each category.}

\begin{tabular}{|c|c|c|c|c|c|c|}
\hline & $\begin{array}{c}\text { Low Interactive } \\
\text { Qualities }\end{array}$ & $\begin{array}{c}\text { Minimum } \\
\text { Interactive } \\
\text { Qualities } \\
\end{array}$ & $\begin{array}{c}\text { Moderate } \\
\text { Interactive } \\
\text { Qualities } \\
\end{array}$ & $\begin{array}{c}\text { Above Average } \\
\text { Interactive } \\
\text { Qualities }\end{array}$ & $\begin{array}{c}\text { High-Level } \\
\text { Interactive } \\
\text { Qualities }\end{array}$ & Score \\
\hline & 1-point & 2-points & 3-points & 4-points & 5-points & \\
\hline $\begin{array}{l}\text { Social/rapport- } \\
\text { building } \\
\text { designs for } \\
\text { interaction }\end{array}$ & $\begin{array}{l}\text { I do not encourage } \\
\text { students to get to } \\
\text { know one another on } \\
\text { a personal basis. } \\
\text { Activities do not } \\
\text { require social } \\
\text { interaction or are } \\
\text { limited to brief } \\
\text { introductions at the } \\
\text { beginning of the } \\
\text { course. }\end{array}$ & $\begin{array}{l}\text { In addition to brief } \\
\text { introductions, I } \\
\text { require one other } \\
\text { exchange of personal } \\
\text { information among } \\
\text { students (e.g. written } \\
\text { bio of personal } \\
\text { background and } \\
\text { experiences). }\end{array}$ & $\begin{array}{l}\text { In addition to brief } \\
\text { introductions, I } \\
\text { provide at least one } \\
\text { other in-class } \\
\text { activity designed to } \\
\text { increase } \\
\text { communication and } \\
\text { social rapport among } \\
\text { students. }\end{array}$ & $\begin{array}{l}\text { In addition to } \\
\text { providing for } \\
\text { exchanges of } \\
\text { personal information } \\
\text { among students and } \\
\text { encouraging } \\
\text { communication and } \\
\text { social interaction, I } \\
\text { also interact with } \\
\text { students on a } \\
\text { social/personal basis. }\end{array}$ & $\begin{array}{l}\text { In addition to } \\
\text { providing for } \\
\text { exchanges of } \\
\text { personal } \\
\text { information and } \\
\text { encouraging } \\
\text { student-student and } \\
\text { instructor-student } \\
\text { interaction, I } \\
\text { provide ongoing } \\
\text { course structures } \\
\text { designed to } \\
\text { promote social } \\
\text { rapport among } \\
\text { students and } \\
\text { instructor. }\end{array}$ & \\
\hline $\begin{array}{l}\text { Instructional } \\
\text { designs for } \\
\text { interaction }\end{array}$ & $\begin{array}{l}\text { Instructional } \\
\text { activities do not } \\
\text { require two-way } \\
\text { interaction between } \\
\text { myself and students; } \\
\text { they call for one-way } \\
\text { delivery of } \\
\text { information (e.g., } \\
\text { instructor lectures, }\end{array}$ & $\begin{array}{l}\text { Instructional } \\
\text { activities require } \\
\text { students to } \\
\text { communicate with } \\
\text { myself on an } \\
\text { individual basis only } \\
\text { (e.g. } \\
\text { asking/responding to } \\
\text { instructor questions). }\end{array}$ & $\begin{array}{l}\text { In addition to the } \\
\text { requiring students to } \\
\text { communicate with } \\
\text { me, instructional } \\
\text { activities require } \\
\text { students to } \\
\text { communicate with } \\
\text { one another (e.g., }\end{array}$ & $\begin{array}{l}\text { In addition to the } \\
\text { requiring students to } \\
\text { communicate with } \\
\text { me, instructional } \\
\text { activities require } \\
\text { students to develop } \\
\text { products by working } \\
\text { together } \\
\text { cooperatively (e.g., }\end{array}$ & $\begin{array}{l}\text { In addition to the } \\
\text { requiring students } \\
\text { to communicate } \\
\text { with me, } \\
\text { instructional } \\
\text { activities require } \\
\text { students to develop } \\
\text { products by } \\
\text { working together }\end{array}$ & \\
\hline
\end{tabular}




\begin{tabular}{|c|c|c|c|c|c|}
\hline & $\begin{array}{l}\text { text delivery) and } \\
\text { student products } \\
\text { based on the } \\
\text { information. }\end{array}$ & & $\begin{array}{l}\text { discussions in pairs } \\
\text { or small groups. }\end{array}$ & $\begin{array}{l}\text { in pairs or small } \\
\text { groups) and sharing } \\
\text { feedback }\end{array}$ & $\begin{array}{l}\text { cooperatively (e.g., } \\
\text { in pairs or small } \\
\text { groups) and share } \\
\text { results and } \\
\text { feedback with other } \\
\text { groups in the class. } \\
\end{array}$ \\
\hline $\begin{array}{l}\text { Interactivity of } \\
\text { technology } \\
\text { resources }\end{array}$ & $\begin{array}{l}\text { Web pages or other } \\
\text { technology resource } \\
\text { allows one-way } \\
\text { delivery of } \\
\text { information (text } \\
\text { and/or graphics). }\end{array}$ & $\begin{array}{l}\text { E-mail, discussion } \\
\text { board or other } \\
\text { technology resource } \\
\text { allows two-way } \\
\text { asynchronous } \\
\text { exchanges of } \\
\text { information (text and } \\
\text { graphics). }\end{array}$ & $\begin{array}{l}\text { In addition to } \\
\text { technologies to allow } \\
\text { two-way exchanges } \\
\text { of information, chat } \\
\text { room or other } \\
\text { technology allows } \\
\text { synchronous } \\
\text { exchanges primarily } \\
\text { in written format. }\end{array}$ & $\begin{array}{l}\text { In addition to } \\
\text { technologies to allow } \\
\text { two-way exchanges } \\
\text { of written } \\
\text { information, } \\
\text { additional } \\
\text { technologies (e.g. } \\
\text { virtual classrooms) } \\
\text { allow one-way visual } \\
\text { and two-way voice } \\
\text { communications } \\
\text { between instructors } \\
\text { and students. }\end{array}$ & $\begin{array}{l}\text { In addition to } \\
\text { technologies to } \\
\text { allow two-way } \\
\text { exchanges of text } \\
\text { information, visual } \\
\text { technologies such } \\
\text { as two-way video } \\
\text { or } \\
\text { videoconferencing } \\
\text { technologies allow } \\
\text { synchronous voice } \\
\& \text { visual } \\
\text { communications } \\
\text { between instructor } \\
\text { and students and } \\
\text { among students. }\end{array}$ \\
\hline $\begin{array}{l}\text { Evidence of } \\
\text { learner } \\
\text { engagement }\end{array}$ & $\begin{array}{l}\text { By the end of the } \\
\text { assignment/activity, } \\
\text { most students (50- } \\
75 \% \text { ) are replying to } \\
\text { messages from me } \\
\text { but only when } \\
\text { required; messages } \\
\text { are sometimes } \\
\text { unresponsive to } \\
\text { topics and tend to be }\end{array}$ & $\begin{array}{l}\text { By the end of the } \\
\text { assignment/activity, } \\
\text { most students (50- } \\
75 \% \text { ) are replying to } \\
\text { messages from me } \\
\text { and other students, } \\
\text { both when required } \\
\text { and on a voluntary } \\
\text { basis; replies are } \\
\text { usually responsive to } \\
\text { topics but often are }\end{array}$ & $\begin{array}{l}\text { By the end of the } \\
\text { assignment/activity, } \\
\text { all or nearly all } \\
\text { students (90-100\%) } \\
\text { are replying to } \\
\text { messages from me } \\
\text { and other students, } \\
\text { both when required } \\
\text { and voluntarily; } \\
\text { replies are always } \\
\text { responsive to topics }\end{array}$ & $\begin{array}{l}\text { By end of the } \\
\text { assignment/activity, } \\
\text { most students are } \\
\text { both replying and } \\
\text { initiating messages } \\
\text { when required and } \\
\text { voluntarily; } \\
\text { messages are } \\
\text { detailed and } \\
\text { responsive to topics } \\
\text { and usually reflect an }\end{array}$ & $\begin{array}{l}\text { By end of the } \\
\text { assignment/activity, } \\
\text { all or nearly all } \\
\text { students }(90-100 \%) \\
\text { are both replying to } \\
\text { and initiating } \\
\text { messages, both } \\
\text { when required and } \\
\text { voluntarily; } \\
\text { messages are } \\
\text { detailed, responsive }\end{array}$ \\
\hline
\end{tabular}




\begin{tabular}{|c|c|c|c|c|c|}
\hline & $\begin{array}{l}\text { either brief or wordy } \\
\text { and rambling. }\end{array}$ & $\begin{array}{l}\text { either brief or wordy } \\
\text { rambling. }\end{array}$ & $\begin{array}{l}\text { but sometimes are } \\
\text { either brief or wordy } \\
\text { and rambling. }\end{array}$ & $\begin{array}{l}\text { effort to } \\
\text { communicate well. }\end{array}$ & $\begin{array}{l}\text { to topics, and are } \\
\text { well-developed } \\
\text { communications. }\end{array}$ \\
\hline $\begin{array}{l}\text { Evidence of } \\
\text { instructor } \\
\text { engagement }\end{array}$ & $\begin{array}{l}\text { I respond only } \\
\text { randomly to student } \\
\text { queries; responses } \\
\text { usually take more } \\
\text { than } 48 \text { hours; } \\
\text { feedback is brief and } \\
\text { provides little } \\
\text { analysis of student } \\
\text { work or suggestions } \\
\text { for improvement. }\end{array}$ & $\begin{array}{l}\text { I respond to most } \\
\text { student queries; } \\
\text { responses are usually } \\
\text { within } 48 \text { hours; } \\
\text { feedback sometimes } \\
\text { offers some analysis } \\
\text { of student work and } \\
\text { suggestions for } \\
\text { improvement. }\end{array}$ & $\begin{array}{l}\text { I respond to all } \\
\text { student queries; } \\
\text { responses are usually } \\
\text { within } 48 \text { hours; } \\
\text { feedback usually } \\
\text { offers some analysis } \\
\text { of student work and } \\
\text { suggestions for } \\
\text { improvement. }\end{array}$ & $\begin{array}{l}\text { I respond to all } \\
\text { student queries; } \\
\text { responses usually are } \\
\text { prompt (i.e., within } \\
24 \text { hours); feedback } \\
\text { always offers } \\
\text { detailed analysis of } \\
\text { student work and } \\
\text { suggestions for } \\
\text { improvement. }\end{array}$ & $\begin{array}{l}\text { I respond to all } \\
\text { student queries; } \\
\text { responses are } \\
\text { always prompt, that } \\
\text { is, within } 24 \text { hours; } \\
\text { feedback always } \\
\text { offers detailed } \\
\text { analysis of student } \\
\text { work and } \\
\text { suggestions for } \\
\text { improvement, along } \\
\text { with additional } \\
\text { hints and } \\
\text { information to } \\
\text { supplement } \\
\text { learning. }\end{array}$ \\
\hline & & & & & Total \\
\hline
\end{tabular}




\section{Appendix J - Student Instructions}

Dear Student:

You are about to complete an online survey regarding your learning experiences in this course module. It will take 10-15 minutes. Whether you participate or not is, of course, up to you. It will not cost you anything. We are asking you to complete survey that we need to help us evaluate the quality and effectiveness of online interactions. While we will need to use it in reports, there will be no names used and there will be no way anyone could trace a particular response back to a particular person. In any case, you should still remember that if there is any item that you want to leave blank, that is OK.

These forms have been approved by the College Human Subjects Committee. If you have any questions about this project, you can contact Dr. Jill Stefaniak 757-6836696 at or Dr. Linda Bol at (757) 683-4584, Beth Oyarzun (910) 962-2417 or Dr. Edward Gomez, the Chair of the Human Subjects Committee in the College of Education 757683-6309.

Your participation in this evaluation will provide valuable information that can use to improve online instruction. You will be prompted to enter a prize drawing at the end of the survey. Several headsets with microphones will be given to the participants drawn at the conclusion of the research study.

To begin the survey (Click here.)

Sincerely,

Beth Oyarzun

Instructional Designer

Office of e-Learning

UNCW 
Creating a Unique Identification Number and e-mail it to your instructor.

\begin{tabular}{|l|l|l|}
\hline Prompts & Your response & Example \\
\hline 1. What is the first letter of your birth month? & & $\mathrm{M}$ \\
\hline 2. Write the first letter of your mother's name. & & $\mathrm{E}$ \\
\hline $\begin{array}{l}\text { 3. How many brothers and sisters do you } \\
\text { have? If none, write 0 }\end{array}$ & 3 \\
\hline $\begin{array}{l}\text { 4. Write the year you graduated from high } \\
\text { school using the last 2 digits. }\end{array}$ & & 77 \\
\hline $\begin{array}{l}\text { 5. Write the first letter of the city where you } \\
\text { were born. }\end{array}$ & W \\
\hline
\end{tabular}

Record your responses to the above questions:

Example: M E $377 \mathrm{~W}$ 


\section{Appendix K - Student Demographic Survey}

1. What is the subject area of your course?

a) Sciences (Biology and Marine Biology, Chemistry, Physics, Computer Science, Environmental Studies, Geography and geology, Math and Statistics, Physics and Oceanography, Pre-engineering)

b) Health and Human Applied Sciences (Nursing, Social Work, and Exercise Science, public health, tourism, recreation therapy, clinical research, physical education)

c) Education

d) Business

e) Social Sciences (Anthropology, Communications, History, International Studies, Public and International affairs, Psychology, Sociology and Criminology)

f) Cultural arts (Art and Art history, Creative Writing, English, Film studies, Foreign Language and Literature, Music, Philosophy and Religion)

g) Other

2. Select your age range.
a) $15-17$
b) $18-24$
c) $24-30$
d) $30-40$
e) $40-50$
f) $50-60$
g) Over 60

3. Select your gender.
a) Male
b) Female

4. What is your student classification?
a) Freshman
b) Sophomore
c) Junior
d) Senior
e) Non-traditional

5. What is your student status?

a) Part-time undergraduate student

b) Full-time undergraduate student

6. What is your current job status?
a) Unemployed
b) Part-time employee
c) Full-time employee 
7. What is your level of computer skill?

a) Minimal Knowledge (not able to do computer related tasks without assistance)

b) Some Knowledge, Need assistance at times (able to power on/off computer, access internet, check e-mail)

c) Comfortable with Computers (Can do some trouble shooting when issues arise, can learn new applications without assistance)

d) Advanced (able to do advanced troubleshooting, the person friends a family call when they need assistance)

8. Approximately how many online classes have you taken?
a) $1-2$
b) $3-4$
c) $5-10$
d) More than 10

9. What communication tools did you use as part of this assignment/activity? (Choose all that apply)
a) Face-to-face meeting
b) Mobile devices - texting/phone calls
c) E-mail
d) Message boards (ex: discussion boards)
e) Instant Messenger (ex: Skype, Google hangouts)
f) Virtual Classroom (ex: WebEx, Go to Meeting)
g) Shared Content Builders (ex: Google drive, Dropbox)
h) Other 


\section{Appendix L - Student Social Presence Scale}

\section{Social Presence Scale}

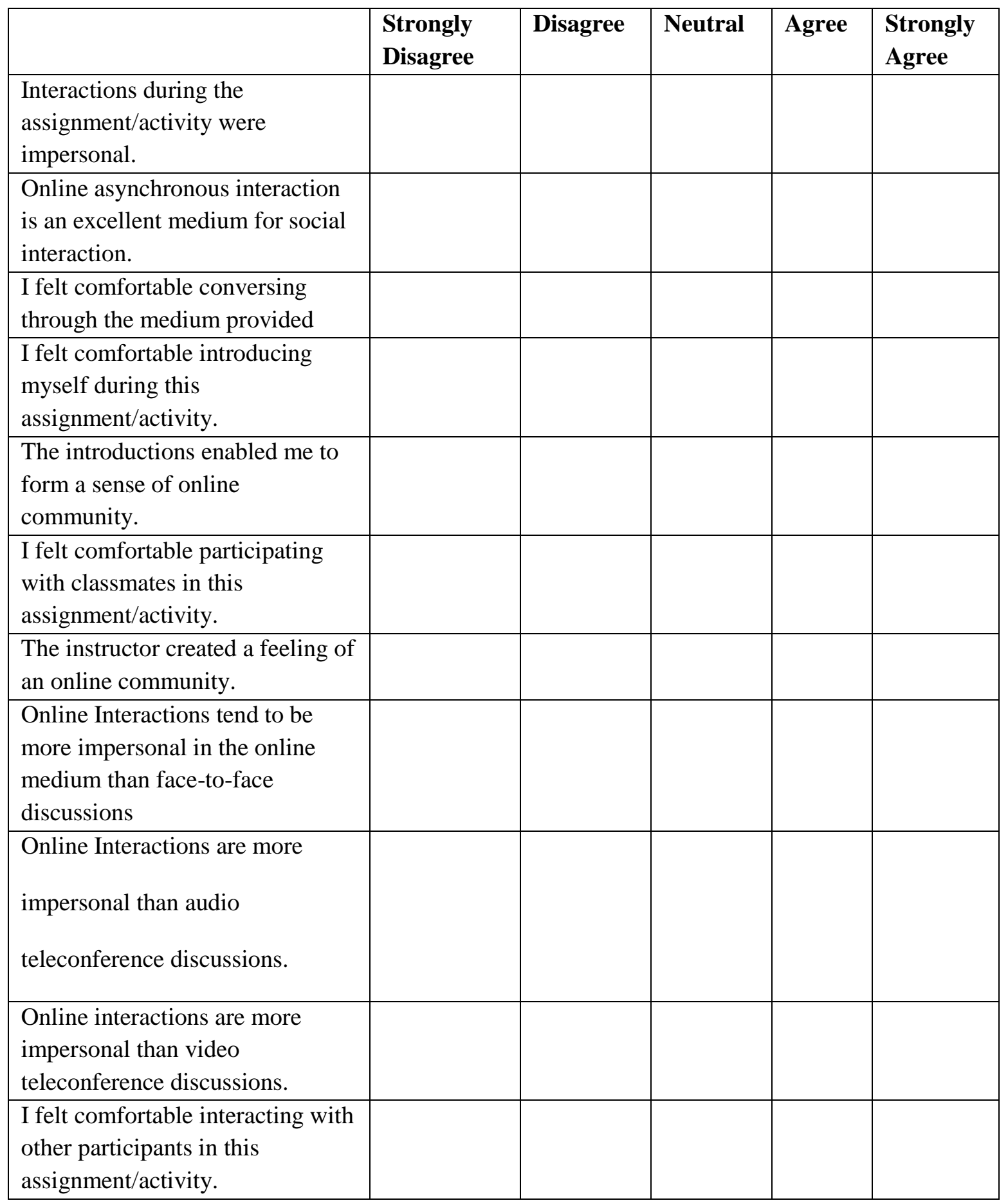




\begin{tabular}{|l|l|l|l|l|l|}
\hline $\begin{array}{l}\text { I felt that other participants in this } \\
\text { assignment/activity } \\
\text { acknowledged my point of view. }\end{array}$ & & & & & \\
\hline $\begin{array}{l}\text { I was able to form distinct } \\
\text { individual impressions of some } \\
\text { participants even though we } \\
\text { communicated only online. }\end{array}$ & & & & & \\
\hline $\begin{array}{l}\text { My Instructor is a caring person } \\
\text { with the students. }\end{array}$ & & & & & \\
\hline $\begin{array}{l}\text { My Instructor is a "real person" } \\
\text { with the students. }\end{array}$ & & & & & \\
\hline $\begin{array}{l}\text { My Instructor is NOT } \\
\text { professional with the students. }\end{array}$ & & & & & \\
\hline $\begin{array}{l}\text { My Instructor is humble with the } \\
\text { students. }\end{array}$ & & & & & \\
\hline $\begin{array}{l}\text { My instructor does NOT provide } \\
\text { open communications. }\end{array}$ & & & & & \\
\hline $\begin{array}{l}\text { My instructor does NOT create } \\
\text { unity. }\end{array}$ & & & & & \\
\hline $\begin{array}{l}\text { My instructor creates an attitude } \\
\text { of sharing. }\end{array}$ & & & & & \\
\hline $\begin{array}{l}\text { My instructor creates an attitude } \\
\text { of group encouragement. }\end{array}$ & & & & & \\
\hline $\begin{array}{l}\text { My instructor does NOT draw the } \\
\text { class together. }\end{array}$ & & & & & \\
\hline $\begin{array}{l}\text { My instructor grades my } \\
\text { performance fairly. }\end{array}$ & & & & & \\
\hline
\end{tabular}




\section{Appendix M - Student Interaction Quality Scale}

\section{Carefully rate interaction quality for each category in the rubric.}

\begin{tabular}{|c|c|c|c|c|c|c|}
\hline & $\begin{array}{c}\text { Low Interactive } \\
\text { Qualities }\end{array}$ & $\begin{array}{c}\text { Minimum } \\
\text { Interactive } \\
\text { Qualities }\end{array}$ & $\begin{array}{c}\text { Moderate } \\
\text { Interactive } \\
\text { Qualities }\end{array}$ & $\begin{array}{c}\text { Above Average } \\
\text { Interactive } \\
\text { Qualities }\end{array}$ & $\begin{array}{l}\text { High-Level } \\
\text { Interactive } \\
\text { Qualities }\end{array}$ & Score \\
\hline & 1-point & 2-points & 3-points & 4-points & 5-points & \\
\hline $\begin{array}{l}\text { Social/rapport- } \\
\text { building designs } \\
\text { for interaction }\end{array}$ & $\begin{array}{l}\text { The instructor does } \\
\text { not encourage } \\
\text { students to get to } \\
\text { know one another } \\
\text { on a personal basis. } \\
\text { Activities do not } \\
\text { require social } \\
\text { interaction or are } \\
\text { limited to brief } \\
\text { introductions at the } \\
\text { beginning of the } \\
\text { course. }\end{array}$ & $\begin{array}{l}\text { In addition to brief } \\
\text { introductions, the } \\
\text { instructor requires } \\
\text { one other exchange } \\
\text { of personal } \\
\text { information among } \\
\text { students (e.g. written } \\
\text { bio of personal } \\
\text { background and } \\
\text { experiences). }\end{array}$ & $\begin{array}{l}\text { In addition to brief } \\
\text { introductions, the } \\
\text { instructor provides } \\
\text { at least one other in- } \\
\text { class activity } \\
\text { designed to increase } \\
\text { communication and } \\
\text { social rapport among } \\
\text { students. }\end{array}$ & $\begin{array}{l}\text { In addition to } \\
\text { providing for } \\
\text { exchanges of } \\
\text { personal information } \\
\text { among students and } \\
\text { encouraging } \\
\text { communication and } \\
\text { social interaction, } \\
\text { the instructor also } \\
\text { interacts with } \\
\text { students on a } \\
\text { social/personal } \\
\text { basis. }\end{array}$ & $\begin{array}{l}\text { In addition to } \\
\text { providing for } \\
\text { exchanges of } \\
\text { personal } \\
\text { information and } \\
\text { encouraging } \\
\text { student-student and } \\
\text { instructor-student } \\
\text { interaction, The } \\
\text { instructor provides } \\
\text { ongoing course } \\
\text { structures designed } \\
\text { to promote social } \\
\text { rapport among } \\
\text { students and } \\
\text { instructor. }\end{array}$ & \\
\hline $\begin{array}{l}\text { Instructional } \\
\text { designs for } \\
\text { interaction }\end{array}$ & $\begin{array}{l}\text { Instructional } \\
\text { activities do not } \\
\text { require two-way } \\
\text { interaction between } \\
\text { instructor and } \\
\text { students; they call } \\
\text { for one-way } \\
\text { delivery of }\end{array}$ & $\begin{array}{l}\text { Instructional } \\
\text { activities require } \\
\text { students to } \\
\text { communicate with } \\
\text { the instructor on an } \\
\text { individual basis only } \\
\text { (e.g. }\end{array}$ & $\begin{array}{l}\text { In addition to the } \\
\text { requiring students to } \\
\text { communicate with } \\
\text { the instructor, } \\
\text { instructional } \\
\text { activities require } \\
\text { students to } \\
\text { communicate with }\end{array}$ & $\begin{array}{l}\text { In addition to the } \\
\text { requiring students to } \\
\text { communicate with } \\
\text { the instructor, } \\
\text { instructional } \\
\text { activities require } \\
\text { students to develop } \\
\text { products by working }\end{array}$ & $\begin{array}{l}\text { In addition to the } \\
\text { requiring students } \\
\text { to communicate } \\
\text { with the instructor, } \\
\text { instructional } \\
\text { activities require } \\
\text { students to develop } \\
\text { products by }\end{array}$ & \\
\hline
\end{tabular}




\begin{tabular}{|c|c|c|c|c|c|}
\hline & $\begin{array}{l}\text { information (e.g., } \\
\text { instructor lectures, } \\
\text { text delivery) and } \\
\text { student products } \\
\text { based on the } \\
\text { information. }\end{array}$ & $\begin{array}{l}\text { asking/responding to } \\
\text { instructor questions). }\end{array}$ & $\begin{array}{l}\text { one another (e.g., } \\
\text { discussions in pairs } \\
\text { or small groups. }\end{array}$ & $\begin{array}{l}\text { together } \\
\text { cooperatively (e.g., } \\
\text { in pairs or small } \\
\text { groups) and sharing } \\
\text { feedback }\end{array}$ & $\begin{array}{l}\text { working together } \\
\text { cooperatively (e.g., } \\
\text { in pairs or small } \\
\text { groups) and share } \\
\text { results and } \\
\text { feedback with other } \\
\text { groups in the class. }\end{array}$ \\
\hline $\begin{array}{l}\text { Interactivity of } \\
\text { technology } \\
\text { resources }\end{array}$ & $\begin{array}{l}\text { Web pages or other } \\
\text { technology } \\
\text { resource allows } \\
\text { one-way delivery } \\
\text { of information (text } \\
\text { and/or graphics). }\end{array}$ & $\begin{array}{l}\text { E-mail, discussion } \\
\text { board or other } \\
\text { technology resource } \\
\text { allows two-way } \\
\text { asynchronous } \\
\text { exchanges of } \\
\text { information (text } \\
\text { and graphics). }\end{array}$ & $\begin{array}{l}\text { In addition to } \\
\text { technologies to } \\
\text { allow two-way } \\
\text { exchanges of } \\
\text { information, chat } \\
\text { room or other } \\
\text { technology allows } \\
\text { synchronous } \\
\text { exchanges primarily } \\
\text { in written format. }\end{array}$ & $\begin{array}{l}\text { In addition to } \\
\text { technologies to } \\
\text { allow two-way } \\
\text { exchanges of written } \\
\text { information, } \\
\text { additional } \\
\text { technologies (e.g. } \\
\text { virtual classrooms) } \\
\text { allow one-way } \\
\text { visual and two-way } \\
\text { voice } \\
\text { communications } \\
\text { between instructors } \\
\text { and students. }\end{array}$ & $\begin{array}{l}\text { In addition to } \\
\text { technologies to } \\
\text { allow two-way } \\
\text { exchanges of text } \\
\text { information, visual } \\
\text { technologies such } \\
\text { as two-way video } \\
\text { or } \\
\text { videoconferencing } \\
\text { technologies allow } \\
\text { synchronous voice } \\
\& \text { visual } \\
\text { communications } \\
\text { between instructor } \\
\text { and students and } \\
\text { among students. }\end{array}$ \\
\hline $\begin{array}{l}\text { Evidence of } \\
\text { learner } \\
\text { engagement }\end{array}$ & $\begin{array}{l}\text { By the end of the } \\
\text { assignment/activity, } \\
\text { most students (50- } \\
75 \% \text { ) are replying } \\
\text { to messages from } \\
\text { the instructor but } \\
\text { only when } \\
\text { required; messages } \\
\text { are sometimes } \\
\text { unresponsive to }\end{array}$ & $\begin{array}{l}\text { By the end of the } \\
\text { assignment/activity, } \\
\text { most students (50- } \\
75 \% \text { ) are replying to } \\
\text { messages from the } \\
\text { instructor and other } \\
\text { students, both when } \\
\text { required and on a } \\
\text { voluntary basis; } \\
\text { replies are usually }\end{array}$ & $\begin{array}{l}\text { By the end of the } \\
\text { assignment/activity, } \\
\text { all or nearly all } \\
\text { students (90-100\%) } \\
\text { are replying to } \\
\text { messages from the } \\
\text { instructor and other } \\
\text { students, both when } \\
\text { required and } \\
\text { voluntarily; replies }\end{array}$ & $\begin{array}{l}\text { By end of the } \\
\text { assignment/activity, } \\
\text { most students are } \\
\text { both replying and } \\
\text { initiating messages } \\
\text { when required and } \\
\text { voluntarily; } \\
\text { messages are } \\
\text { detailed and } \\
\text { responsive to topics }\end{array}$ & $\begin{array}{l}\text { By end of the } \\
\text { assignment/activity, } \\
\text { all or nearly all } \\
\text { students }(90-100 \%) \\
\text { are both replying to } \\
\text { and initiating } \\
\text { messages, both } \\
\text { when required and } \\
\text { voluntarily; } \\
\text { messages are }\end{array}$ \\
\hline
\end{tabular}




\begin{tabular}{|l|l|l|l|l|l|}
\hline & $\begin{array}{l}\text { topics and tend to } \\
\text { be either brief or } \\
\text { wordy and } \\
\text { rambling. }\end{array}$ & $\begin{array}{l}\text { responsive to topics } \\
\text { but often are either } \\
\text { brief or wordy } \\
\text { rambling. }\end{array}$ & $\begin{array}{l}\text { are always } \\
\text { responsive to topics } \\
\text { but sometimes are } \\
\text { either brief or wordy } \\
\text { and rambling. }\end{array}$ & $\begin{array}{l}\text { and usually reflect } \\
\text { an effort to } \\
\text { communicate well. }\end{array}$ & $\begin{array}{l}\text { detailed, responsive } \\
\text { to topics, and are } \\
\text { well-developed } \\
\text { communications. }\end{array}$ \\
\hline $\begin{array}{l}\text { Evidence of } \\
\text { instructor } \\
\text { engagement }\end{array}$ & $\begin{array}{l}\text { Instructor responds } \\
\text { only randomly to } \\
\text { student queries; } \\
\text { responses usually } \\
\text { take more than 48 } \\
\text { hours; feedback is } \\
\text { brief and provides } \\
\text { little analysis of } \\
\text { student work or } \\
\text { suggestions for } \\
\text { improvement. }\end{array}$ & $\begin{array}{l}\text { Instructor responds } \\
\text { to most student } \\
\text { queries; responses } \\
\text { are usually within } 48 \\
\text { hours; feedback } \\
\text { sometimes offers } \\
\text { some analysis of } \\
\text { student work and } \\
\text { suggestions for } \\
\text { improvement. }\end{array}$ & $\begin{array}{l}\text { Instructor responds } \\
\text { to all student } \\
\text { queries; responses } \\
\text { are usually within 48 } \\
\text { hours; feedback } \\
\text { usually offers some } \\
\text { analysis of student } \\
\text { work and } \\
\text { suggestions for } \\
\text { improvement. }\end{array}$ & $\begin{array}{l}\text { Instructor responds } \\
\text { to all student } \\
\text { queries; responses } \\
\text { usually are prompt } \\
\text { i.e., within 24 } \\
\text { hours); feedback } \\
\text { always offers } \\
\text { detailed analysis of } \\
\text { student work and } \\
\text { suggestions for } \\
\text { improvement. }\end{array}$ & $\begin{array}{l}\begin{array}{l}\text { Instructor responds } \\
\text { to all student } \\
\text { queries; responses } \\
\text { are always prompt, } \\
\text { that is, within 24 } \\
\text { hours; feedback } \\
\text { always offers } \\
\text { detailed analysis of } \\
\text { student work and } \\
\text { suggestions for } \\
\text { improvement, } \\
\text { along with } \\
\text { additional hints and } \\
\text { information to } \\
\text { supplement } \\
\text { learning. }\end{array} \\
\text { Total }\end{array}$ \\
\hline
\end{tabular}




\section{Appendix N - Student Satisfaction Survey}

\begin{tabular}{|l|l|l|l|l|l|}
\hline & $\begin{array}{l}\text { Strongly } \\
\text { Disagree }\end{array}$ & Disagree & Neutral & Agree & $\begin{array}{l}\text { Strongly } \\
\text { Agree }\end{array}$ \\
\hline $\begin{array}{l}\text { I was able to learn through online using } \\
\text { the strategy provided. }\end{array}$ & & & & & \\
\hline $\begin{array}{l}\text { I was able to learn from discussions with } \\
\text { classmates. }\end{array}$ & & & & & \\
\hline $\begin{array}{l}\text { I was stimulated to do additional reading } \\
\text { or research on topics discussed the } \\
\text { assignment/activity. }\end{array}$ & & & & & \\
\hline I learned to value other points of view. & & & & & \\
\hline $\begin{array}{l}\text { As a result of my experience in this } \\
\text { assignment/activity, I would like to } \\
\text { participate in another assignment/activity } \\
\text { using the same strategy provided. }\end{array}$ & & & & & \\
\hline $\begin{array}{l}\text { This assignment/activity was a useful } \\
\text { learning experience. }\end{array}$ & & & & & \\
\hline $\begin{array}{l}\text { As a result of my participation in this } \\
\text { assignment/activity, I made acquaintances } \\
\text { electronically with classmates. }\end{array}$ & & & & & \\
\hline $\begin{array}{l}\text { I put in a great deal of effort to learn the } \\
\text { communication tools to participate in this } \\
\text { assignment/activity. }\end{array}$ & & & & & \\
\hline
\end{tabular}




\title{
VITA
}

\author{
Susan Elizabeth Allred Oyarzun \\ 7016 Orchard Trace \\ Wilmington, NC 28409 \\ (910)200-5907 (C) \\ (910)962-2417 (O) \\ beth@oyarzun.net \\ http://beth836.wix.com/oyarzun
}

\section{ACADEMIC DEGREES}

2009-2016 Ph.D. in Instructional Design and Technology, Old Dominion University

Dissertation Title: Effects of Learner-to-Learner Interactions on Social Presence, Achievement and Satisfaction

2001-2005 Master of Science in Instructional Technology, University of North Carolina Wilmington

1991-1996 Bachelor of Arts in Mathematics with Secondary Certification, University of North Carolina Wilmington

\section{TEACHING EXPERIENCE}

2005 - 2014 Undergraduate Level, University of North Carolina Wilmington

- Instructional Technology (EDN 303)

Delivered face-to-face and fully online

Emphasizes the design, selection, production and evaluation of instructional materials, computer generated presentation, and interactive media for instructional purposes.

- Instructional Design (EDN 301)

Delivered face-to-face and fully online

Provides conceptual tools and analytic skills essential for planning, implementing and evaluating instruction.

- Instructional Design, Technology, and Evaluation (SEC 300)

Delivered fully online

Provides conceptual tools and analytic skills essential for designing effective instructional activities that incorporate technology as well as field based experiences for implementing, and evaluating lessons.

- Freshman Seminar (UNI 101)

Delivered face-to-face

Seminar course designed to support first-year students in optimizing their college experience. 
2015 - Graduate Level, University of North Carolina Charlotte

- Instructional Design (EIST 6110)

Delivered fully online

Instructional analysis, design and evaluation principles and practices; gaining practical experience applying theoretical understandings of instructional design principles and processes such as goal and task analysis, learner and context analysis, instructional strategies, selection and development of instructional materials, and formative and summative evaluation.

- Foundations of Instructional Systems Technology (EIST 6100) Delivered fully online

Contemporary issues and historical development of instructional systems technology; an overview of learning theory, instructional systems analysis and design, instructional design models, technology innovations and factors affecting the use of technology for learning.

- Learning, Media, Resources, and Technology (EIST 6135) Delivered fully online

Selection, use, and evaluation of technological innovations in instructional media. Students learn to make professionally sound decisions in selecting appropriate processes and resources to provide optimal conditions for learning based on principles, theories, and effective practices.

2014- Graduate Level, University of North Carolina Wilmington

- Computer Based Instruction (MIT 513)

Delivered simultaneously synchronous online and face-to-face

Emphasizes the design, develop and evaluate an interactive computer-based instructional program that meets instructional needs.

- Technology in Higher Education (EDL 556)

Delivered fully online

Provides the opportunity for a critical survey of social media, mobile devices and applications used by students and professionals in postsecondary education contexts.

1996-2001 High School Level

- Algebra I

- Geometry

- Algebra 2

- Trigonometry

- AP statistics 


\section{PROFESSIONAL EXPERIENCE}

2010 - Instructional Designer, Office of e-Learning, Academic Affairs University of North Carolina Wilmington

- Founder and Manager of the Excellence in e-Learning faculty award

- Design, Develop, and Deliver professional development for faculty.

- Design, Develop, and Diffuse training materials on e-Learning technologies

- Assist faculty with design, development, and implementation of completely online and hybrid courses and programs

- Research, implement, and disseminate emerging e-Learning technologies

- WebEx Administrator

- ShareStream Administrator

- QM Coordinator

2005-2010 Emerging Technology Liaison, Watson School of Education, University of North Carolina Wilmington

- Design, Develop, and Deliver professional development for faculty, interns, and public school partners

- Design, Develop, and Diffuse training materials on emerging instructional technologies

- Assist faculty with design, development, and implementation of completely online and hybrid courses and programs

- Research, implement, and disseminate emerging instructional technologies

2007-2007 Faculty Representative of the Learning Management System Transition Team, Instructional Technology Systems Division, University of North Carolina Wilmington

- Planned and implemented the transition from WebCT Campus Edition to Blackboard Vista

2001-2005 Teacher, Ashley High School

- Taught AP Statistics, Algebra I, Geometry, Algebra 2 and Trigonometry

- NovaNET Computer Lab Director

- Junior and Senior Class Advisor

2002-2005 Graduate Instructional Technology Assistant, School of Nursing University of North Carolina Wilmington 
- Assisted professors in developing, loading, and maintaining their fully online and hybrid courses

2005-2005 Graduate Instructional Technology Assistant, Information Technology Systems Division, University of North Carolina Wilmington

- Conducted needs assessments

- Developed web pages for various departments

2005-2005 Graduate Instructional Technology Assistant, Watson School of Education, University of North Carolina Wilmington

- Assisted Professional Development System director in developing professional presentations

1997-2000 Teacher, South Brunswick High School

- AP Statistics, Advanced math, Algebra II, and Algebra I

- Junior Varsity and Varsity cheerleading coach

1996-1997 Teacher, Swansboro High School

- Algebra I and Technical Mathematics

- Junior Varsity cheerleading coach

\section{PUBLICATIONS}

Oyarzun, B. A. \& Morrison, G. R. (2013). Cooperative Learning Effects on Achievement and Community of Inquiry in Online Education. Quarterly Review of Distance Education. 14(4), 181-194, 255.

Anderson, S., Oyarzun, B. (2013). Multi-modal Professional Development for Faculty. In Keengwe, J., \& Kyei-Blankson, L. (2013). Virtual Mentoring for Teachers: Online Professional Development Practices (pp. 1-383). doi:10.4018/978-1-46661963-0

Oyarzun, B., \& Martin, F. (2013). A Case Study on Multi-Modal Course Delivery and Social Learning Opportunities. Bulletin of the IEEE Technical Committee on Learning Technology, 15(1), 25-28.

Martin, F., Parker, M. \& Allred, B. (2013). A Case Study on the adoption and use of synchronous virtual classrooms, Electronic Journal of E-learning, 11, 2, 124-128

Ritzhaupt, A. D., Higgins, H., \& Allred, S. B. (2011). Effects of modern educational game play on attitudes towards mathematics, mathematics self-efficacy, and mathematics achievement. Journal of Interactive Learning Research, 22(2), 277297. 
Ritzhaupt, A. D., Higgins, H., \& Allred, S. B. (2010). Teacher experiences on the integration of modern educational games in the middle school mathematics classroom. Journal of Computers in Mathematics and Science Teaching, 29(2), 189-216.

\section{PRESENTATIONS \& WORKSHOPS}

Oyarzun, B. (2015, October). Cooperative Learning Effects on Achievement and Community of Inquiry in Online Education Courses. Online Learning Consortium International Conference. Orlando, FL.

Garrett-Dikkers, A. \& Oyarzun, B. (2015, October). Applied Learning in Higher Education Online and Blended Environments. Online Learning Consortium International Conference. Orlando, FL.

Oyarzun, B. (2015, June). Best Practices in Online Course Development and Delivery. College of Health and Applied Human Services, UNCW, Wilmington, NC.

Oyarzun, B \& Anderson, S. (2015, June) Best Practices in Online Course Development and Delivery. i3@UNC!, Wilmington, NC.

Oyarzun, B. Martin, F., Pastore, R., Maddrell, J., \& Anderson, S. (October, 2014). MultiModal Course Delivery: Face-to-Face and Online Students Together. Presented at Association of Educational Communications and Technology Conference, Jacksonville, FL.

Oyarzun, B. (October, 2013). Cooperative Learning effects in Online Learning. Presented at the Global Learning Technologies Conference, Wilmington, NC.

Oyarzun, B., Anderson, S. (July, 2012). Blackboard, Moodle, Edmodo? What? Learning Management System Basics. Workshop presented at the Global Learning Technologies Conference, Wilmington, NC.

Dowd, J., Boyce, R., Anderson, S., Oyarzun, B., League, H. (July, 2012). E-Learning Pilot for Human Anatomy and Physiology: Student Perceptions of "Mastering A $\& P$ ”. Presented at the Global Learning Technologies Conference, Wilmington, NC.

Anderson, S., Oyarzun, B., Kinney, J. (July 2012). Getting Connected Through Online Lectures. Presented at the Global Learning Technologies Conference, Wilmington, NC. 
Anderson, S., Allred, B., Gonzalez, P. (July, 2011) Engaging your Synchronous Class from a Student's Perspective. Presented at the Blackboard Collaborate Connections Summit. Las Vegas, Nevada.

Anderson, S., Allred, B., Gonzalez, P. (April, 2011) Lights, Camera, Action! Incorporating Videos into Online or Web-enhanced Courses. Presented at the Teaching and Learning with Technology Conference. Second Life

Anderson, S., Allred, B., Gonzalez, P. (April, 2011) Engaging your Synchronous Class from a Student's Perspective. Presented at the Teaching and Learning with Technology Conference. Second Life

Anderson, S., Reid-Griffin, A., Allred, B. (January, 2011) Blackboard 9 - Portfolio Features. Presented at the Hawaii International Conference on Education. Honolulu, Hawaii.

Martin, F., \& Parker, M.A, \& Allred, B. (2010, October). Adoption of Virtual Classrooms for Online Courses in Higher Education. Presented at Association of Educational Communications and Technology Conference, Anaheim, CA.

Ritzhaupt, A. D., Higgins, H. \& Allred S. B. (June, 2010). Teacher voices on integrating games in middle school classrooms. Presented at the International Society for Technology in Education, Denver, CO.

Ritzhaupt, A. D., Higgins, H. \& Allred S. B. (June, 2010). Modern educational games and middle school mathematics. Presented at the International Society for Technology in Education, Denver, CO.

Ritzhaupt, A. D., Higgins, H. \& Allred S. B. (May, 2010). Teacher experiences on the integration of modern educational games in the middle school mathematics classroom. Presented at the American Educational Research Association, Denver, $\mathrm{CO}$.

Ritzhaupt, A. D., Higgins, H. \& Allred S. B. (May, 2010). Effects of modern educational game play on attitudes towards mathematics, mathematics self-efficacy, and mathematics achievement. Presented at the American Educational Research Association, Denver, CO.

Allred, B. \& Siko, K. L. (April, 2010). Assistive Technology meets Video Game Technology: A case study in the use of video game hardware for assistive technology purpose. Presented at the Society for Information Technology and Teacher Education Conference, San Diego, CA. 
Ritzhaupt, A. D., Higgins, H. \& Allred S. B. (October, 2009). Effects of serious game play on mathematics achievement and self-efficacy. Presented at the Association of Educational and Communication Technology, Louisville, KY.

Parker, M. A., Martin, F., \& Allred, S. E., (2009, October). The Effect of Faculty and Student Personality Type on Perceptions of Learning through Virtual Classrooms. Presented at Association of Educational Communications and Technology Conference, Louisville, KY.

Allred B. (March, 2009) Social Networking: Meeting Beginning Teachers on their Turf. Presented at the North Carolina Mentoring $21^{\text {st }}$ Century Educators Conference. Wilmington, NC.

Parker, M., Allred, B., Martin, F., Ndoye, A. \& Reid-Griffin, A. (March, 2009). Aligning Nets-T standards (NETS-T 2008) with Technology Products. Presented at Society for Information Technology and Teacher Education Conference. Charleston, SC.

Martin, F., Parker, M., Reid-Griffin, A., Allred, B. \& Ndoye, A. (March, 2009). Efolio

Technologies for Digital Students. Presented at Society for Information

Technology and Teacher Education Conference. Charleston, SC.

Allred, B., Anderson, S., Mcquiston, P. (March, 2008). $21^{\text {st }}$ Century Mentoring - Using Technology to Enhance Mentoring Strategies. Invited Keynote Speaker of the North Carolina Mentoring $21^{\text {st }}$ Century Educators Conference. Wilmington, NC.

Summerville, J., Allred, B. (March, 2007) Cheating in the Cyberworld. Presented at the Teaching and Learning with Technology Conference. Raleigh, NC.

Summerville, J., Allred, B. (March, 2006) Cheating in the Cyberworld. Presented at the Association of Educational and Communication Technology. Dallas, TX.

Allred, B., Metcalf, E. (February, 2005) Overview of Outreach Alliance Initiatives with Public School Partners. Presented at the College Access Conference. Asheville, NC.

\section{SERVICE}

\section{University of North Carolina Wilmington}

2016 Learning Management Administrator Hiring Committee

2011-2015 Instructional Technology Program Capstone Committees

2005-2015 M.S. in Instructional Technology Program Committee

2005-2015 EDN 303-Instructional Technology Curriculum Committee

2005-2015 EDN 301- Instructional Design Curriculum Committee

2009-2010 SACS Accreditation Committee 
2014 Instructional Designer Hiring Committee

2014-2015 Instructional Technology Program Comprehensive Exam Committees

$2012 \quad$ Bookstore RFP Committee

2008 Instructional Technology Faculty Hiring Committee

2007 E-Learning Analyst Hiring Committee

2007 Instructional Technology Faculty Hiring Committee

2007 Blackboard Administrator Hiring Committee

2006 Middle School Mathematics Faculty Hiring Committee

\section{Professional Organizations}

2012- $\quad$ AECT Conference Proposal Reviewer

2012- $\quad$ AECT Conference Session Facilitator

2012- Blackboard Exemplary Course Reviewer

\section{Community}

2005 - $\quad$ Senior Project Judge for Ashley High School

2010 - Science Fair and Digital Literacy Judge for Isaac Bear Early College

2014 - 2015 Colonial Academic Alliance Pedagogy Summit Planning Committee

2013 Global Learning Technology Conference Planning Committee

2012 Global Learning Technology Conference Planning Committee Chair

\section{GRANTS}

University of North Carolina Wilmington - eTeal Grant (2015) - \$3,500

Proposal Title - Creating an applied learning component in a Leadership and Management nursing course.

University of North Carolina Wilmington - eTeal Grant (2015) - \$3, 499.00

Proposal Title - Developing and electronic product providing research and best practice on how to implement applied learning into courses in an online learning environment.

University of North Carolina Wilmington - IT Innovations Grant (2007) - \$5000

Proposal Title - Assistive Technology meets Video Game Technology: A case study in the use of video game hardware for assistive technology purposes.

University of North Carolina Wilmington - Technology Mini Grant (2005) - \$2000

Proposal Title - Create the opportunity for EDN 303 Instructional technology students to observe and use emerging technologies as teaching and learning tools.

\section{PROFESSIONAL ASSOCIATIONS}

Association of Educational Communication and Technology, 2005 -present 
Online Learning Consortium, 2012 - present

Phi Delta Kappa, 2005 - 2009

International Society for Technology in Education, 2007 - 2008

\section{HONORS AND AWARDS}

2016

2014

2014

2005-2007

2001-2012
Alan Mandell Endowed Award for Instructional Design \& Technology

AECT Pacificorp Design and Development Competition Finalist

UNCW Staff Award for Excellence Nominee

Vice President of Programs for Phi Delta Kappa Educational Society

National Board Certified Teacher in Early/Young Adulthood Mathematics

\section{TECHNICAL SKILLS}

\begin{tabular}{|l|l|l|l|l|}
\hline LMS & $\begin{array}{l}\text { Screen } \\
\text { Capture }\end{array}$ & $\begin{array}{l}\text { Adobe } \\
\text { Products }\end{array}$ & $\begin{array}{l}\text { Virtual } \\
\text { Communicati } \\
\text { on }\end{array}$ & $\begin{array}{l}\text { Office } \\
\text { Products }\end{array}$ \\
\hline $\begin{array}{l}\text { BB Vista - A, } \\
\text { I }\end{array}$ & Camtasia & Premiere & Skype - I, S & Word \\
\hline $\begin{array}{l}\text { BB Learn - A, } \\
\text { I }\end{array}$ & Snag-It & Dreamweaver & Bb IM - I & PowerPoint \\
\hline Moodle - A, I & Jing & Photoshop & $\begin{array}{l}\text { WebEx - A, I, } \\
\text { S }\end{array}$ & Excel \\
\hline $\begin{array}{l}\text { WebCT 4.0 - } \\
\text { A, I, S }\end{array}$ & Captivate & Illustrator & $\begin{array}{l}\text { Second Life - } \\
\text { A, I, S }\end{array}$ & Outlook \\
\hline $\begin{array}{l}\text { BB Enterprise } \\
- \text { S }\end{array}$ & Articulate & InDesign & $\begin{array}{l}\text { Google Apps } \\
- \text { I, S }\end{array}$ & Publisher \\
\hline
\end{tabular}

A - Administrator Experience, I - Instructor Experience, S - Student Experience 